\title{
CCN2/CTGF promotor activity in the developing and adult mouse eye
}

\author{
Andrea E. Dillinger ${ }^{1} \cdot$ Sabrina Kuespert $^{1} \cdot$ Franziska Froemel $^{1} \cdot$ Ernst R. Tamm $^{1} \cdot$ Rudolf Fuchshofer $^{1}$ (I)
}

Received: 27 April 2020 / Accepted: 29 October 2020 / Published online: 29 January 2021

(c) The Author(s) 2021

\begin{abstract}
$\mathrm{CCN} 2 / \mathrm{CTGF}$ is a matricellular protein that is known to enhance transforming growth factor- $\beta$ signaling and to induce a myofibroblast-like phenotype in a variety of cell types. Here, we investigated $C \mathrm{cn} 2 / \mathrm{Ctg} f$ promotor activity during development and in the adult mouse eye, using $C T G F^{L a c Z /+}$ mice in which the $\beta$-galactosidase reporter gene LacZ had been inserted into the open reading frame of $C c n 2 / C t g f$. Promotor activity was assessed by staining for $\beta$-galactosidase activity and by immunolabeling using antibodies against $\beta$-galactosidase. Co-immunostaining using antibodies against glutamine synthetase, glial fibrillary acidic protein, choline acetyltransferase, and CD31 was applied to identify specific cell types. Ccn2/ $C t g f$ promotor activity was intense in neural crest-derived cells differentiating to corneal stroma and endothelium, and to the stroma of choroid, iris, ciliary body, and the trabecular meshwork during development. In the adult eye, a persistent and very strong promotor activity was present in the trabecular meshwork outflow pathways. In addition, endothelial cells of Schlemm's canal, and of retinal and choroidal vessels, retinal astrocytes, Müller glia, and starburst amacrine cells were stained. Very strong promoter activity was seen in the astrocytes of the glial lamina at the optic nerve head. We conclude that CCN2/CTGF signaling is involved in the processes that govern neural crest morphogenesis during ocular development. In the adult eye, CCN2/CTGF likely plays an important role for the trabecular meshwork outflow pathways and the glial lamina of the optic nerve head.
\end{abstract}

Keywords Eye development $\cdot$ Trabecular meshwork $\cdot$ Glial lamina $\cdot$ Neural crest $\cdot$ Astrocyte

\section{Introduction}

CCN2 is a member of the cellular communication network (CCN) family of extracellular matrix-associated and heparinbinding matricellular proteins (Brigstock 2003; Leask 2020; Perbal and Perbal 2016; Perbal 2013, 2018). It is more commonly known under its original name connective tissue growth factor (CTGF) that was recently discontinued by the HUGO Gene Nomenclature Committee which adopted the use of CCN2 instead (Perbal et al. 2018). Because of the fairly recent change and for the sake of clarity, we will continue to use the term CCN2/CTGF throughout this contribution. Like other members of the CCN family, CCN2/CTGF is structurally characterized by four conserved, cysteine-rich domains. The domains consist of the insulin-like growth factor binding protein (IGFBP) domain, the von Willebrand

Rudolf Fuchshofer

rudolf.fuchshofer@ur.de

1 Institute of Human Anatomy and Embryology, University of Regensburg, 93053 Regensburg, Germany type $\mathrm{C}$ repeats (vWC) domain, the thrombospondin type 1 repeat (TSR) domain, and a C-terminal domain (CT) with a cysteine knot motif.

Studies in $C c n 2 / C t g f$-deficient mice show an important role of CCN2/CTGF for proper development of cartilage, vasculature, and pancreatic islets (Crawford et al. 2009; HallGlenn et al. 2012; Ivkovic et al. 2003). In the adult organism, a major function of CCN2/CTGF is the amplification of transforming growth factor- $\beta$ (TGF- $\beta$ ) signaling by both activating latent TGF- $\beta$ and enhancing its binding to the TGF- $\beta$ receptor II (Abreu et al. 2002; Gressner et al. 2009; Khankan et al. 2011; Mori et al. 1999). TGF- $\beta$ signaling is further augmented through the TGF- $\beta$-induced increase in $C \mathrm{cn} 2 /$ $C t g f$ expression that has been consistently observed in many different cell types (Fuchshofer et al. 2009, 2007; Grotendorst et al. 1996; Holmes et al. 2001; Igarashi et al. 1993; Leask et al. 2001). CCN2/CTGF is highly overexpressed in conditions associated with increased extracellular matrix (ECM) synthesis and fibrosis such as scleroderma (Sato et al. 2000; Yamamoto et al. 2005), diabetic nephropathy and kidney fibrosis (Mason 2013; Yin and Liu 2019), fibrotic liver 
diseases (Gressner and Gressner 2008), idiopathic pulmonary fibrosis (Richeldi et al. 2020), or glaucoma (Browne et al. 2011; Ho et al. 2020; Wallace et al. 2013). In fibrotic conditions, $\mathrm{CCN} 2 / \mathrm{CTGF}$ appears to be primarily involved in the differentiation of resident cells into myofibroblasts (Kapoor et al. 2008; Liu et al. 2010), a highly specialized cell type of variable origin that combines extracellular matrix synthesis with contractility (Bochaton-Piallat et al. 2016; Carthy 2018; Hinz et al. 2007, 2012).

The role of CCN2/CTGF in myofibroblast differentiation is also seen in normal cell types with myofibroblast-like characteristics such as the trabecular meshwork in the eye (Braunger et al. 2015a; Tamm et al. 2015). Depletion of CCN2/CTGF in trabecular meshwork cells causes a substantial loss of their actin cytoskeleton while its overexpression increases trabecular meshwork contractility and extracellular matrix production (Junglas et al. 2012). The increase in trabecular meshwork contractility causes dysfunction of the aqueous humor outflow pathways, high intraocular pressure and glaucoma (Junglas et al. 2012; Reinehr et al. 2019). In the present study, we wanted to learn more about the specific cell types that express CCN2/ CTGF in the eye. Immunohistochemical studies are available that studied its localization in ocular tissues (Pi et al. 2011; van Setten et al. 2016). Still such studies offer only limited information about the cellular expression of Ccn2/Ctgf as it is a secreted molecule that binds with high affinity to heparan sulfate proteoglycans and other molecules on cellular surfaces. For this reason, cellular immunoreactivity for CCN2/CTGF might not necessarily indicate its cellular origin. We therefore studied Ccn2/Ctgf promotor activity in $C T G F^{L a c Z /+}$ mice in which the $\beta$-galactosidase marker gene $\mathrm{LacZ}$ has been inserted into the open reading frame of $C \mathrm{cn} 2 / \mathrm{Ctg}$ (Crawford et al. 2009). Here, we report about distinct and hitherto not identified cellular sites of substantial Ccn2/Ctgf expression during ocular development and in the adult eye.

\section{Material and methods}

\section{Animals}

In $C T G F^{L a c Z /+}$ mice, the $\beta$-galactosidase marker gene $\mathrm{LacZ}$ was inserted into the open reading frame of Ccn2/Ctgf (Crawford et al. 2009). In this study, we used heterozygous $C T G F^{L a c Z /+}$ mice to investigate the distribution pattern of $C c n 2 / C t g f$ promotor activity during eye development. $C T G F^{\text {LacZ/+ }}$ mice were found to be viable and fertile corroborating previous observations (Crawford et al. 2009). $\mathrm{CTGF}^{\text {LacZ/LacZ }}$ animals were not included in this study as homozygous deficiency causes severe skeletal and vascular abnormalities leading to the death of the animals at birth (Ivkovic et al. 2003). We expected that $C c n 2 / C t g f$ promoter activity under this condition would not necessarily reflect that of wild-type mice. Mice were housed under standardized conditions of $62 \%$ air humidity and $21{ }^{\circ} \mathrm{C}$ room temperature (RT). Feeding was ad libitum. Animals were kept at a $12 \mathrm{~h}$ light/dark cycle (6:00-18:00). All procedures conformed to the tenets of the National Institutes of Health Guidelines on the Care and Use of Animals in Research, the EU Directive 2010/63/E and the ARVO Statement for the Use of Animals in Ophthalmic and Vision Research, and were approved by the local authorities (54-2532.1-44/12; Regierung Oberpfalz, Bavaria, Germany). Before enucleation of the eyes, mice were anesthetized with $\mathrm{CO}_{2}$ and euthanized by atlanto-occipital dislocation.

\section{RNA analysis}

Total RNA from sensory retinal tissue was extracted with TriFast $^{\mathrm{TM}}$ (Peqlab, Erlangen, Germany) according to the manufacturer's recommendations. cDNA was prepared from total RNA using the $\mathrm{qScript}^{\mathrm{TM}} \mathrm{cDNA}$ Synthesis Kit (Quanta Biosciencies Gaithersburg, USA) according to the manufacturer's instructions. Real-time RT-PCR was performed on a BioRad CFX Real-Time PCR Detection System (BioRad, Munich, Germany) with the temperature profile as follows: 50 cycles of $20 \mathrm{~s}$ melting at $94{ }^{\circ} \mathrm{C}, 10 \mathrm{~s}$ of annealing at $60^{\circ} \mathrm{C}$, and $20 \mathrm{~s}$ of extension at $60^{\circ} \mathrm{C}$. All primers were purchased from Invitrogen (Carlsbad, USA) and extended over exon-intron boundaries. CTGF forward 5'TGA CCTGGAGGAAAACATTAAGA3', CTGF reverse 5'AGC CCTGTATGTCTTCACACTG3', RPL32 forward 5'GCT GCCATCTGTTTTACGG3', RPL32 reverse 5'TGACTGGTG CCTGATGAACT3'. RNA that was not reverse transcribed served as negative control. For relative quantification of the experiments, RPL32 was used as a housekeeping gene. Quantification was performed using BioRad CFX Manager software version 3.1.1517.0823 (BioRad).

\section{Western blot analysis}

Proteins were isolated following the RNA isolation according to the manufacturer's recommendations (Peqlab). Proteins were dissolved in $1 \%$ SDS containing protease and phosphatase inhibitors, and protein content was measured with the bicinchoninic acid assay (Interchim, Montluçon Cedex, France). Western blot analysis was performed with specific antibodies as described previously (Fuchshofer et al. 2011, 2007). Specific antibodies were used as follows: goat anti-CTGF (1:500, Santa Cruz Biotechnology, Santa Cruz, USA), rabbit anti- $\alpha$-tubulin (1:2500, Rockland Immunochemicals Inc., Gilbertsville, USA), donkey antigoat (1:2000, Bethyl Laboratories Inc., Montgomery, USA), and goat anti-rabbit (1:5000, Cell Signaling Technology, Danvers, USA). Chemiluminescence was detected on a LAS 
3000 imaging workstation (Fujifilm, Düsseldorf, Germany). For normalization of the signal intensity, $\alpha$-tubulin was used as a loading control. The intensity of the bands detected by Western blotting was determined using appropriate software (AIDA Image analyzer software, Raytest, Straubenhardt, Germany).

\section{Microscopy and quantitative morphometry}

For light and transmission electron microscopy, eyes were obtained from young adult animals at 9 weeks of age. Eyes were enucleated and fixed in Karnovsky's solution (2.5\% glutaraldehyde and $2.5 \%$ paraformaldehyde in $0.1 \mathrm{M}$ cacodylate buffer) for $24 \mathrm{~h}$ (Karnovsky 1965). After rising in $0.1 \mathrm{M}$ cacodylate buffer, postfixation was accomplished in a mixture of $1 \% \mathrm{OsO}_{4}$ and $0.8 \%$ potassium ferrocyanide in $0.1 \mathrm{M}$ cacodylate buffer for $2 \mathrm{~h}$ at $48^{\circ} \mathrm{C}$. After dehydration in a graded series of ethanol, the eyes were embedded in Epon (Serva, Heidelberg, Germany). Semithin sections $(1 \mu \mathrm{m})$ were collected on uncoated glass slides and stained with methylene blue/azure II (Richardson et al. 1960). Ultrathin sections were mounted on uncoated copper grids, stained with uranyl acetate and lead citrate, and examined on a Zeiss Libra transmission electron microscope (Carl Zeiss AG). Quantitative morphometry of the retina was performed on semithin sections. The length of each retinal hemisphere was divided through 10, and the thickness at each point was measured. Means of the measured points were plotted in a spider diagram and statistical analysis was performed to compare single measure points of $C T G F^{L a c Z /+}$ and WT mice. Thickness of Descemet's membrane was measured at 6 measure points in the peripheral cornea of semithin sections.

\section{Staining for $\beta$-galactosidase activity}

Eyes of mice at different ages (postnatal days (P) 1, 5, 10, 15, $20,49)$ were used. Embryos were obtained from timed matings with noon of the day of vaginal plug discovery designated as 0.5 days of gestation (E 0.5). Ccn2/Ctgf promotor activity was analyzed at E11.5 and E16.5. Eyes and embryos were fixed with $2 \%$ glutaraldehyde in $5 \mathrm{mM}$ egtazic acid (EGTA; $\mathrm{pH}$ 7.3) and $2 \mathrm{mM} \mathrm{MgCl}$ dissolved in $0.1 \mathrm{M}$ phosphate buffer for $30 \mathrm{~min}$ at RT. Followed by three washing steps with washing buffer $\left(1 \mathrm{M} \mathrm{MgCl}_{2}, 1 \% \mathrm{NaDC}, 2 \%\right.$ Tergitol in $0.1 \mathrm{M}$ phosphate buffer), samples were immersed for $24 \mathrm{~h}$ at $37{ }^{\circ} \mathrm{C}$ in the dark with $\mathrm{X}-\mathrm{Gal}$ staining solution $(2 \mathrm{mM}$ $\mathrm{MgCl}_{2}, 0.01 \%$ sodium deoxycholate, $0.02 \%$ Nonidet-P40, $5 \mathrm{mM}$ potassium ferrocyanide, $5 \mathrm{mM}$ potassium ferricyanide, $1 \mathrm{mg} / \mathrm{ml} \mathrm{X}$-Gal dissolved in $0.1 \mathrm{M}$ phosphate buffer) to visualize $\beta$-galactosidase activity. Afterwards, samples were washed three times for $10 \mathrm{~min}$ with washing buffer, followed by a second washing step for three times for $10 \mathrm{~min}$ with $0.1 \mathrm{M}$ phosphate buffer. After incubation for $1 \mathrm{~h}$ with $50 \%$ isopropanol and $1 \mathrm{~h}$ with $70 \%$ isopropanol, samples were embedded in paraffin. Finally, $6 \mu \mathrm{m}$ sections were cut on a Supercut microtom (Reichert-Jung, Kirchseeon, Germany).

\section{Immunohistochemistry}

Eyes were enucleated and fixed in $4 \%(\mathrm{w} / \mathrm{v})$ paraformaldehyde overnight or $2 \mathrm{~h}$ for retinal flat mount preparation. Eyes were equilibrated in $10 \%, 20 \%$, and $30 \%$ sucrose, embedded in Tissue-Tek optimal cooling temperature compound (Sakura Finetek Europe B.V., Zoeterwounde, Netherlands) and stored at $-20{ }^{\circ} \mathrm{C}$. Frozen $12 \mu \mathrm{m}$ sections were cut on a cryostat. For retinal flat mounts, the whole retina was dissected and put on an object slide. Retinal flat mounts were pretreated with $50 \mathrm{mM} \mathrm{NH}_{4} \mathrm{Cl}(1 \mathrm{~h}, \mathrm{RT})$ and $0.5 \%$ Triton-X-100 (30 min, RT). Afterwards, sections and retinal flat mounts were incubated with $2 \%$ bovine serum albumin, $0.2 \%$ cold water fish gelatin, $0.1 \%$ Triton X-100 in $0.1 \mathrm{M}$ phosphate buffer and stained with specific antibodies as follows: rabbit anti$\beta$-galactosidase (1:100, ICL Lab, Portland, USA), chicken anti-GFAP (1:2000, LifeSpan Biosciences, Seattle, USA), goat anti-glutamine synthetase (1:100, Santa Cruz), goat anti-CD31 (1:100, R\&D systems, Minneapolis, USA), goat anti-choline acetyltransferase (1:50, Chemicon International Inc., Temecula, USA), goat anti-Cy ${ }^{\mathrm{TM}} 3 \mathrm{IgG}$ (1:2000, Jackson Research Laboratories, West Grove, USA), Alexa Fluor ${ }^{\circledR}$ 647 donkey anti-rabbit $\operatorname{IgG}(\mathrm{H}+\mathrm{L})(1: 200$, Invitrogen), Alexa Fluor ${ }^{\circledR} 488$ goat anti-chicken $\operatorname{IgG}(\mathrm{H}+\mathrm{L})(1: 1000$, Invitrogen), Alexa Fluor ${ }^{\circledR} 488$ donkey anti-goat IgG $(\mathrm{H}+\mathrm{L})(1: 1000$, Biotium Inc, Fremont, USA), biotinylated anti-rabbit IgG $(\mathrm{H}+\mathrm{L})$ (1:500, Vector Laboratories, Burlingame, USA), and Streptavidin Alexa Fluor ${ }^{\circledR} 488$ (1:1000, Invitrogen). To control for unspecific binding of the secondary antibody, negative controls were performed in which primary antibodies had been omitted. Finally, 4,6-diamidino-2-phenylindoel (DAPI, Vector Laboratories) was added to counterstain nuclear DNA.

\section{Light and fluorescence microscopy}

After immunohistochemical staining and staining for $\beta$-galactosidase activity, tissue sections and retinal flat mounts were analyzed using a Zeiss Axio Imager microscope (Carl Zeiss AG, Jena, Germany).

\section{Results}

To analyze the amounts of CCN2/CTGF in $C T G F^{\text {LacZ/+ }}$ mice with one null allele of $C c n 2 / C t g f$, we performed real-time RT-PCR and Western blot analyses using RNA or protein extracts isolated from the sensory retina of the mice at the age of 4 weeks. Analysis of retinal mRNA showed an approx. 
$50 \%$ reduction of $C c n 2 / C t g f$ mRNA expression in $C T G F^{L a c Z /+}$ mice $(0.50 \pm 0.12, * p=0.02, n=4)$ when compared to their wild type (WT) littermates $(1 \pm 0.14, n=3$; Fig. $1 \mathrm{a})$. The decrease in mRNA expression correlated with a decrease in the amounts of CCN2/CTGF which were significantly reduced $(0.57 \pm 0.35 ; * p=0.04, n=6)$ when compared to those of WT littermates $(1 \pm 0.23, n=6$; Fig. $1 \mathrm{~b})$. The lack of one functional $C c n 2 / C t g f$ allele did neither cause obvious structural nor ultrastructural changes in young adult mice at 9 weeks of age (Fig. 2). More specifically, the cornea was completely transparent in all investigated animals. The corneal stroma of Ccn2/Ctgf mice did not differ from that of WT mice, neither in structure nor in amount of its collagen layers. (Fig. 2 a and a'; $C T G F^{\text {LacZ/+ }} n=6$; WT $n=5$ ). Both in WT and mutant mice, Descemet's membrane (DM) was entirely composed of electron dense material with its characteristic banding pattern (Fig. 2 b and b'). Thickness of Descemet's membrane did not differ between $C T G F^{\text {LacZ/+ }}$ mice $(2.26 \pm 0.24 \mu \mathrm{m} ; n=4)$ and their WT littermates $(2.21 \pm 0.09 \mu \mathrm{m}, \mathrm{n}=2)$, and was similar as observed by others in wild-type mice at the same age and with a similar genetic background (Jun et al. 2006). The inner surface of the cornea was entirely covered by endothelial cells and no signs of corneal vascularization were observed in any of the investigated animals (Fig. 2 a and a'; $C T G F^{\text {LacZ/+ }} n=6$; WT $n=5$ ).

The anterior chamber angle was wide open, and trabecular meshwork and Schlemm's canal were clearly visible in both groups (Fig. 2 a and a'). Moreover, the ultrastructural analysis of the conventional outflow pathways showed no structural differences between $C T G F^{\text {LacZ/+ }}$ mice and their WT littermates. Schlemm's canal endothelium was normally formed showing giant vacuoles and the typical discontinuous basement membrane. In the juxtacanalicular region of the trabecular meshwork outflow pathways we observed in both groups regularly formed collagen fibrils and elastic fibers interrupted by optically empty spaces (Fig. 2 c and c').

In both $C T G F^{\text {LacZ/+ }}$ mice and their WT littermates, the retina showed its normal layers (Fig. $2 \mathrm{~d}$ and d'). Moreover, the thicknesses of the outer nuclear layer and inner nuclear layer of $C T G F^{\text {LacZ/+ }}$ and WT littermates at the age of 2 months were not significantly different $(n=3)$ (Fig. 2 e and f). Taken together, reduction of CCN2/CTGF in heterozygous deficient $C T G F^{\text {LacZ/+ }}$ mice did not cause phenotypic changes, a finding that is in agreement with previous studies focusing on the retinal vasculature (Kuiper et al. 2007, 2008).

To analyze $C \operatorname{cn} 2 / C t g f$ promotor activity during embryonic development, we took advantage of the fact that in $C T G$ $F^{\mathrm{LacZ} /+}$ mice, the $\beta$-galactosidase marker gene $L a c Z$ had been inserted into the open reading frame of $\mathrm{Ccn} 2 / \mathrm{Ctgf}$. At embryonic day (E) 11.5 during formation of the lens vesicle and the optic cup all cell types of the developing eye stained positive for $\beta$-galactosidase including those of the surrounding neural crest (Fig. 3a). At E16.5, the neural crest cells forming the sclera and the stroma of the developing choroid, ciliary body, and iris were labelled intensely for $\beta$-galactosidase (Fig. 3b). In addition, cells of both corneal epithelium and endothelium stained positive as did the cells of the lens epithelium. Positive staining was absent in lens fibers. Cells of the retinal pigment epithelium were essentially negative and the sensory retina showed only weak labeling in its anterior inner parts. Positive labeling continued to the inner epithelium of the a

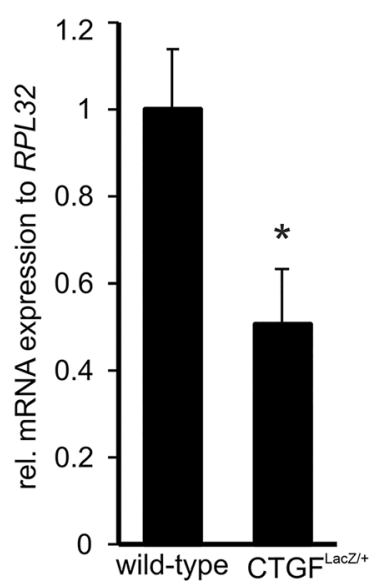

b

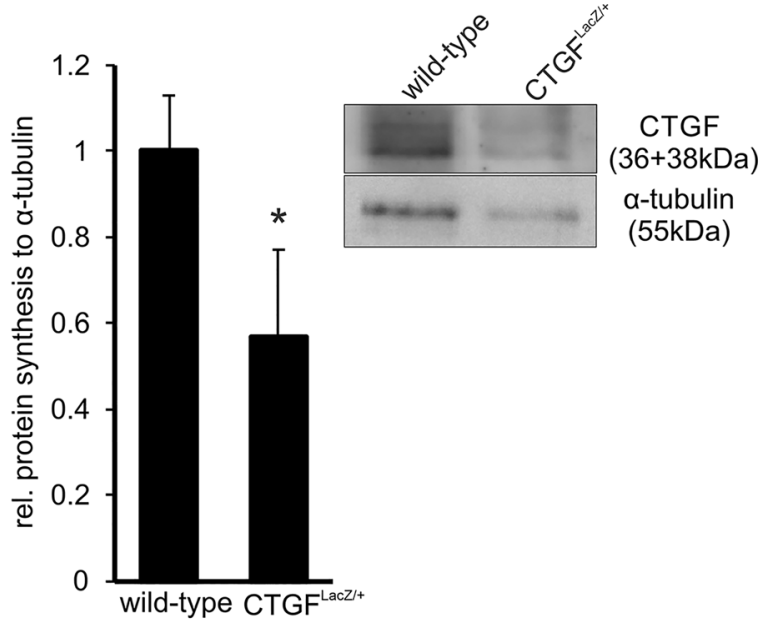

Fig. $1 \mathrm{CCN} 2 / \mathrm{CTGF}$ and its mRNA in the sensory retina of $C T G$ $F^{\text {LacZ/+ }}$ and wild-type mice at the age of 4 weeks. a Real-time RTPCR for $C c n 2 / C t g f$ mRNA in $C T G F^{\text {LacZl+ }}$ mice compared to wildtype littermates $\left({ }^{*} p=0.02\right)$. RPL32 was used as a housekeeping gene for analysis. b Western blot analysis for CCN2/CTGF in CTGF ${ }^{\text {LacZ/+ }}$ mice when compared to wild-type controls $\left({ }^{*} p=0.04\right)$. Two bands migrating at $36 \mathrm{kDa}$ and $38 \mathrm{kDa}$ are detected corresponding to the molecular weight of CCN2/CTGF and its modified form (Junglas et al. 2009). $\alpha$-Tubulin was used for normalization of Western blot signal intensity. Mean values of wild-type controls were set at 1 . Data represented as mean \pm SEM 

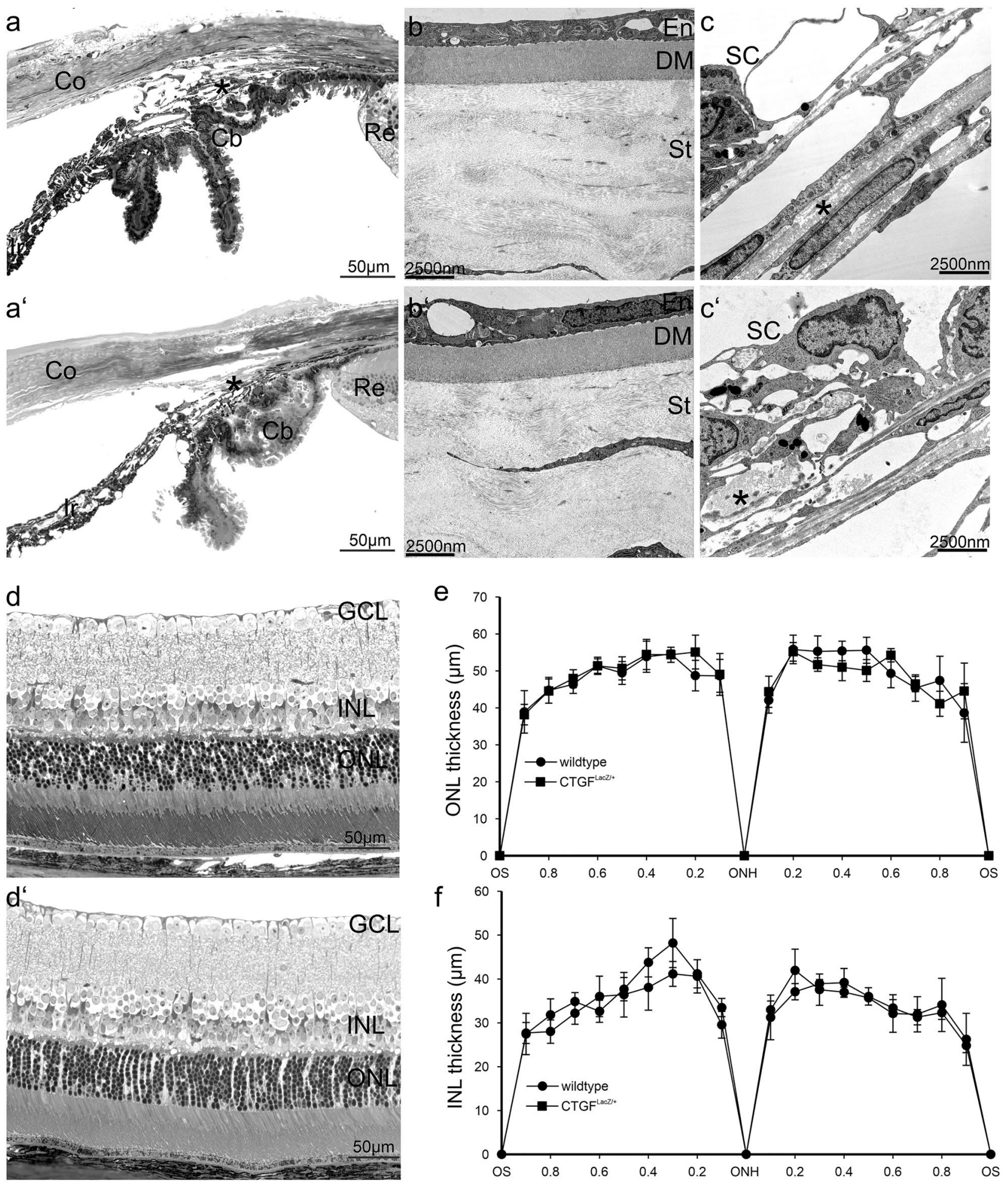

Fig. 2 a Represented images of semithin sections of the iridocorneal angle and the cornea of WT mice a and $C T G F^{\mathrm{LacZ}++}$ a' at the age of 9 weeks. There are no obvious morphological changes in $C T G F^{\text {LacZ/+ }}$ mice compared to control mice. b The ultrastructure of the cornea shows a regular orientation of the collagen bundles in the corneal stroma, the DM is composed entirely of electron dense material and with the characteristic banding pattern in the WT mice b and $C T G$ $F^{\text {LacZ }+}$ b'. c The Schlemm's canal endothelium and the juxtacanalicular trabecular meshwork showed the normal ultrastructural compo-

sition of the outflow tissues with a regular formed ECM (asterisk) in WT mice $\mathbf{c}$ and $C T G F^{\mathrm{LacZ}+} \mathbf{c}^{\prime}$. d Representative images of semithin sections of the central retina of WT mice $\mathbf{d}$ and $C T G F^{\mathrm{LacZ} /+} \mathbf{d}$ ' at the age of 9 weeks. There are no obvious morphological changes in $C T G$ $F^{\text {LacZ/+ }}$ mice compared to control mice. The thickness of ONL e and INL was quantified at 21 measure points on horizontal paraffin sections stretching from the nasal to temporal side through the ONH. The results are presented in spider diagrams. Data is represented as mean \pm SEM, $n=3$ 
Fig. 3 Ccn $2 / C t g f$ promotor activity during embryonic and postnatal development of $C T G$ $F^{\text {LacZ/+ }}$ mice. a, b Histological staining of $\beta$-galactosidase activity on embryonic day (E) $11.5 \mathbf{a}$ and E16.5 $\mathbf{b}$ of the developing mouse eye of $C T G$ $F^{\text {LacZ/+ }}$ mice. At E11.5, all cell types during formation of the lens vesicle and the optic cup, including those of the surrounding neural crest are positive for $\beta$-galactosidase. At E16.5, neural crest cells forming the sclera and the stroma of the developing choroid, ciliary body, and iris are labelled intensely. Additionally, the epithelium and endothelium of the cornea and the lens epithelium is positive for $\beta$-galactosidase. c At P1, the staining of $\beta$-galactosidase activity is similar compared to E16.5. d At P5, positive staining of $\beta$-galactosidase in the optic nerve is seen. e At P10, the first individual cells in the retina are positively stained and remain so until adulthood, while the staining in the sclera, cornea, and lens were barely detectable. f, $\mathbf{g}$ Throughout postnatal development and in adulthood, staining for $\beta$-galactosidase is intense in the stroma of the ciliary body and the adjacent tissue of the chamber angle including the trabecular meshwork. h Histological staining of $\beta$-galactosidase activity of wild-type littermates on the adult mouse eye shows no staining. Re retina, Le lens, Co cornea. *Optic nerve head. $n \geq 3$
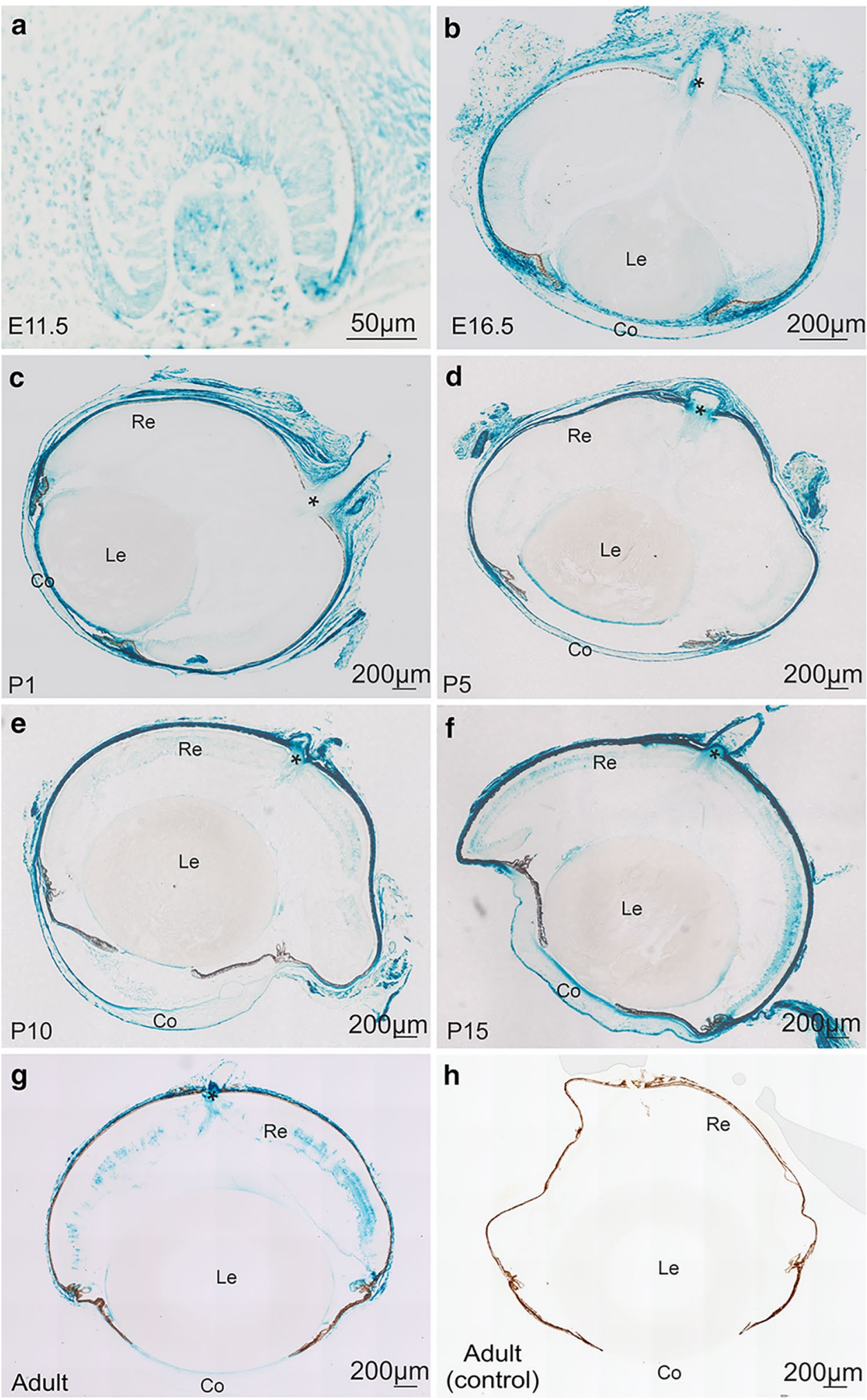

h

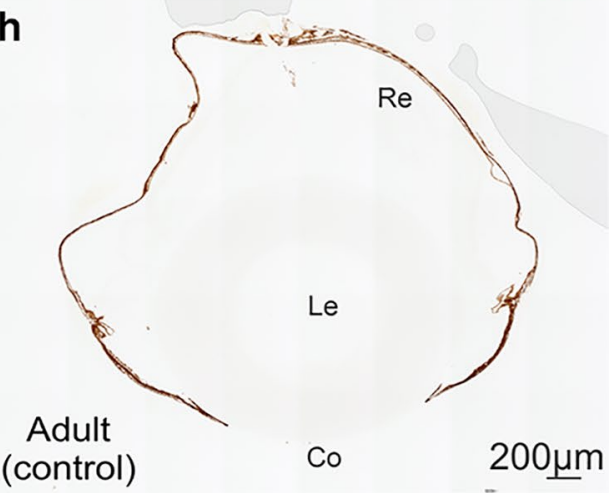

optic cup anterior lip in region of the developing iris/ciliary body cells. At the developing optic nerve its surrounding meninges showed staining for $\beta$-galactosidase as did cells of the hyaloid artery passing through the optic nerve. Eyes of newborn mice (postnatal day (P1)) showed an essentially similar staining pattern (Fig. 3c). At P5, a distinct labeling was first observed at the optic nerve head that corresponded to the site of the developing glial lamina. Labeling of the 
glial lamina was also present at later stages and in adult eyes. A distinct staining of individual cells in the sensory retina became apparent at $\mathrm{P} 10$ and extended until adulthood (Fig. 3e-g). Simultaneously, the positive staining of sclera, cornea and lens became weaker and was barely detectable in adult eyes. Throughout postnatal life and in adulthood, staining for $\beta$-galactosidase was always intense in the stroma of the ciliary body and the adjacent tissues of the chamber angle including the trabecular meshwork (Fig. 3c-g). When control eyes of wildtype littermates where processed for $\beta$-galactosidase, no staining was detected (Fig. 3h).

\section{Ccn2/Ctgf expression in the anterior eye}

Upon higher magnification of the developing cornea and lens, we observed that cells did not stain homogenously for $\beta$-galactosidase (Fig. $4 \mathrm{a}-\mathrm{g}$ ). In contrast, the staining was especially intense in distinct focal regions which we attributed to the fact that high amounts of the enzyme were present in the perinuclear endoplasmic reticulum causing local high enzymatic activity to process X-gal. Co-labeling with antibodies against $\beta$-galactosidase and DAPI to visualize nuclei showed perinuclear immunolabeling and supported our assumption (Fig. 4h, i). The staining pattern was intense from E16.5 to P10 in the epithelial layers of lens and cornea, and in the corneal endothelium (Fig. 4a-d). At P10 and P15, additional labeling was observed in keratocytes of the corneal stroma (Fig. 4d, e). Staining of the lens epithelium was much weaker when eyes from P15 to adulthood were investigated (Fig. 4e). The same was the case for all corneal cell types at P20 and later (Fig. 4f, g).

In the chamber angle region, positive labelling of the stroma in the developing iris/ciliary body was intense at E16.5 and remained so in postnatal life until adulthood (Fig. 5a-f). Between P5 and 15, there was an additional very intense labeling in the limbus area marking the transition between cornea and sclera (Fig. 5c-e). Since during that time period the trabecular meshwork outflow pathways including Schlemm's canal and its collector channels develop in the mouse eye (Cvekl and Tamm 2004), we aimed at identifying more about the nature of the $\beta$-galactosidase-positive cells in this region. To this end, we again performed immunohistochemistry as the blue reaction product of the $\beta$-galactosidase stain tends to diffuse in regions of high $L a c Z$ expression. By using immunolabeling, we identified as site of the highest expression in the P15 anterior eye the pigmented ciliary epithelium (Fig. 5g). In addition, we confirmed that the neural crestderived cells of the anterior eye such as stroma cells of iris/ ciliary body and adjacent choroid, chamber angle and corneal endothelium express $\beta$-galactosidase (Fig. 5 g). Corroborating

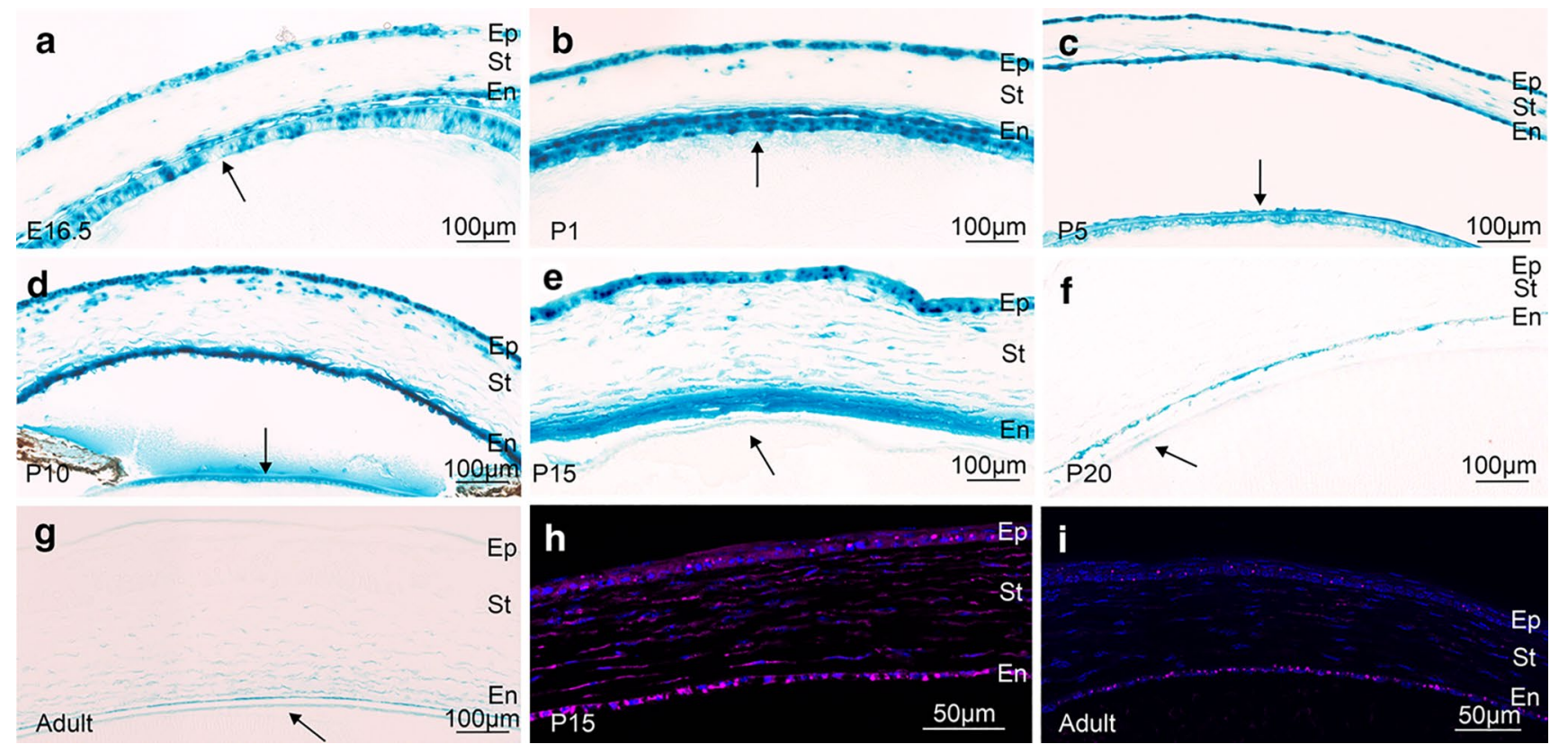

Fig. $4 C c n 2 / C t g f$ promotor activity in the cornea and lens epithelium of $C T G F^{\mathrm{LacZ} /+}$ mice. Histological staining of $\beta$-galactosidase activity is intense from E16.5 to P10 in the epithelial layers of lens (arrow) and cornea, and in the corneal endothelium a-d. At P10 and P15, additional labeling is observed in keratocytes of the corneal stroma d, e. The staining of the lens epithelium is weaker from P15 to adulthood $\mathbf{e}-\mathbf{g}$. The same is the case for all corneal cell types at adulthood g. Immunohistochemical staining against $\beta$-galactosidase (purple) shows an intense immunoreactivity in the epithelium, endothelium, and stroma of the cornea at P15 h. $\beta$-Galactosidase immunoreactivity is much weaker in all corneal cell types in the adult eye $\mathbf{i}$. Nuclei are stained with DAPI. Ep corneal epithelium, St corneal stroma, En corneal endothelium. Arrow indicates lens epithelium. $n \geq 3$ 

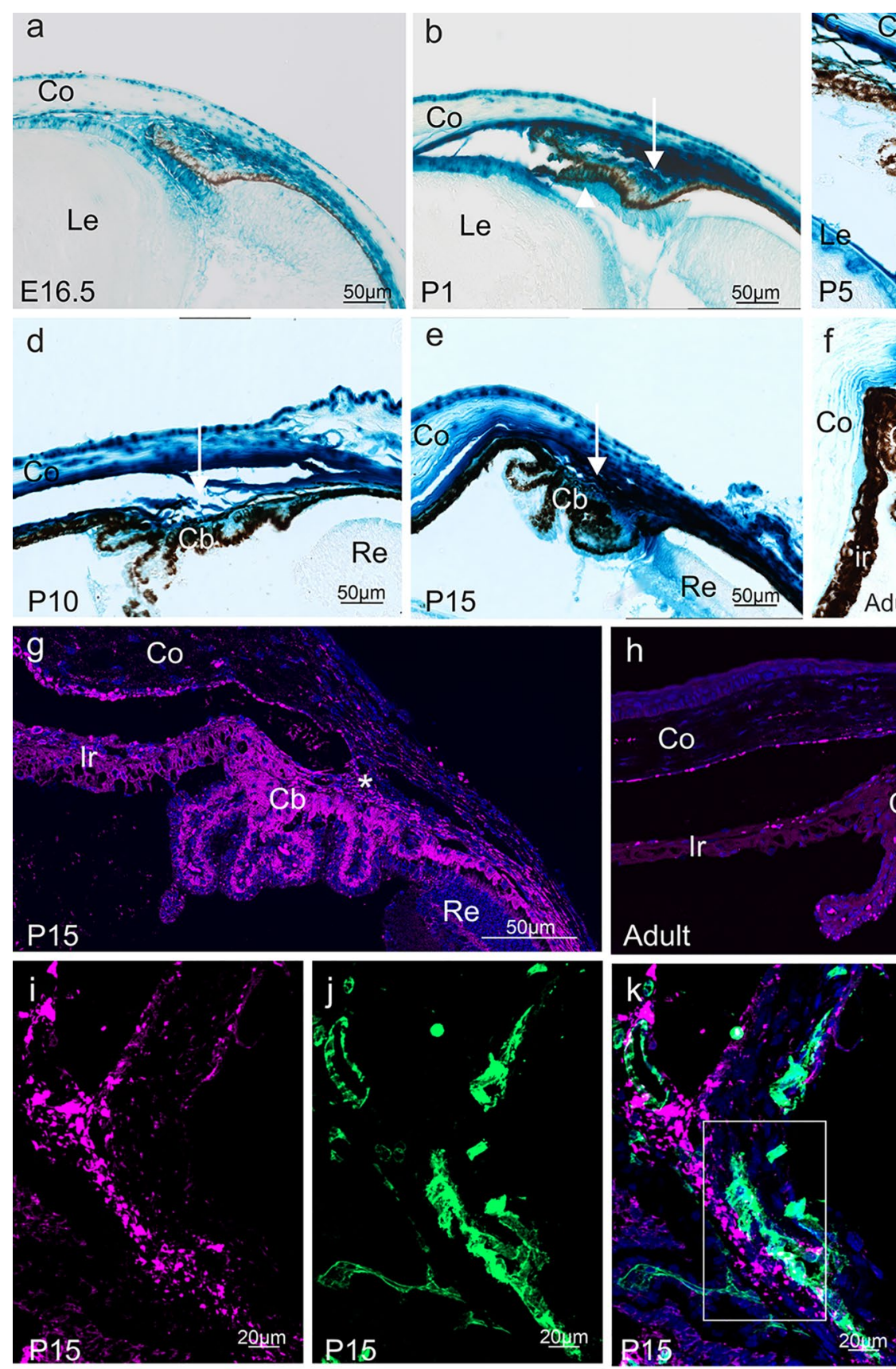

$\mathrm{Cb}$

Re
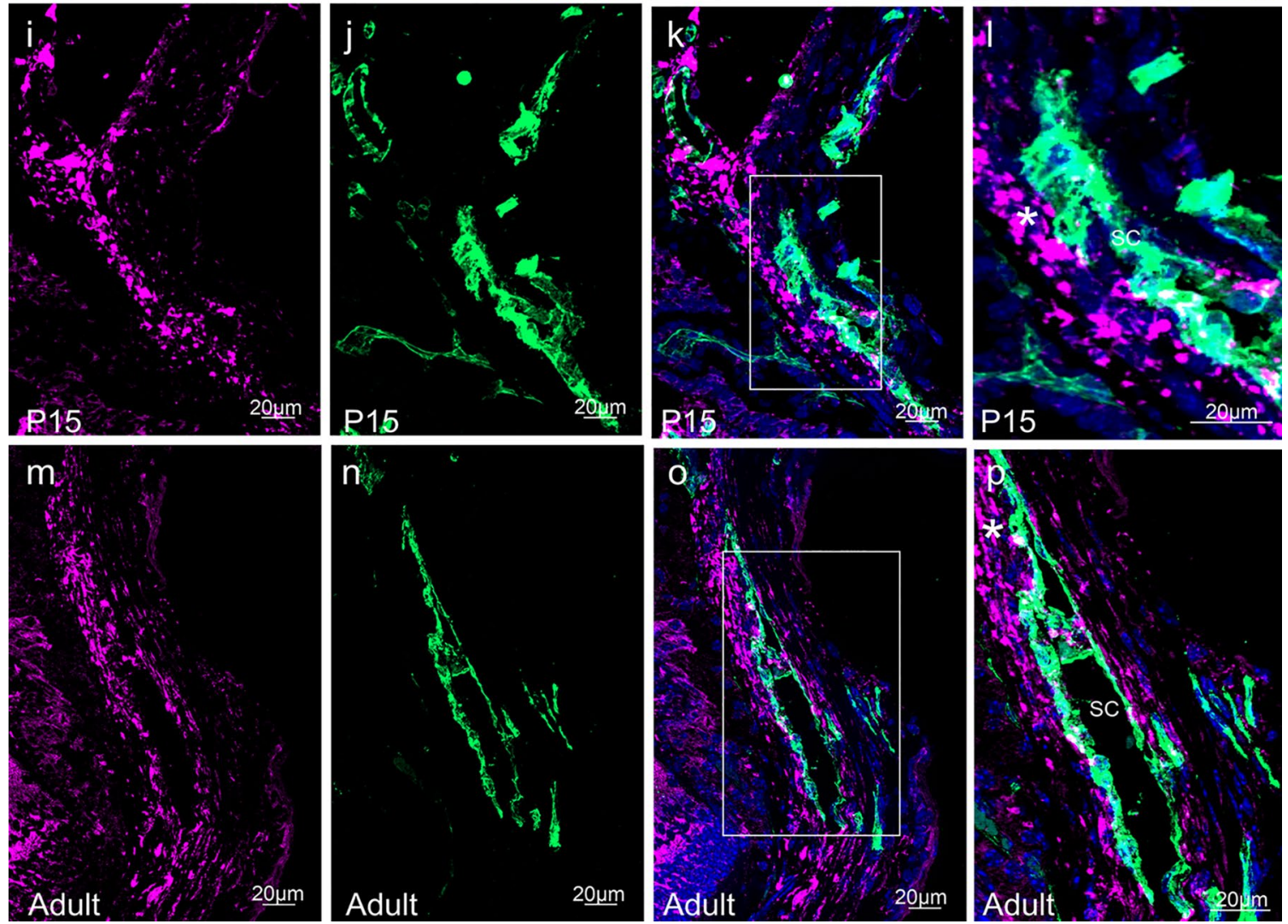
4 Fig. 5 Ccn2/Ctgf promotor activity in the anterior eye segment of $C T G F^{\text {LacZ/+ }}$ mice. Histological a-f and immunohistochemical $\mathbf{g}$, h $\beta$-galactosidase staining of the developing iridocorneal angle at E16.5, P1, P5, P10, P15, and the adult mouse eye. Histological staining for $\beta$-galactosidase activity is intense throughout postnatal development and in adulthood in the stroma of the ciliary body and the adjacent tissues of the chamber angle including the trabecular meshwork (arrow). Immunohistochemical staining against $\beta$-galactosidase (purple) shows the highest expression in the pigmented ciliary epithelium at P15. Furthermore, stroma cells of iris/ciliary body and adjacent choroid, chamber angle, and corneal endothelium express $\beta$-galactosidase. Immunoreactivity is also detected in cells of the limbus region. In the adult eye, immunoreactivity of $\beta$-galactosidase is markedly weaker in cells of the anterior uvea and ciliary epithelium but remains intense in the region of the trabecular meshwork outflow pathways (asterisk). Nuclei are stained with DAPI. i-p Immunohistochemical staining against $\beta$-galactosidase (purple) and CD31 (green) identifies cells in the inner wall endothelium of Schlemm's canal as a source of the Ccn2/Ctg $f$ promotor activity at P15 $\mathbf{i}-\mathbf{l}$ and in the adult eye $\mathbf{m}-\mathbf{p}$. Nuclei are stained with DAPI. Co cornea, Ir Iris, Cb ciliary body, Re retina, SC Schlemm's canal. $n \geq 3$

our findings seen after X-gal histochemistry, immunoreactivity for $\beta$-galactosidase was detected in the cells of the limbus region. In the adult eye, $\beta$-galactosidase immunoreactivity was markedly weaker in cells of anterior uvea and ciliary epithelium but remained intense in region of the trabecular meshwork outflow pathways (Fig. 5h). To identify which cell type of the outflow pathways expresses $\beta$-galactosidase, we performed double-immunohistochemistry with antibodies against $\beta$-galactosidase and CD31 (Fig. $5 \mathrm{i}-\mathrm{p}$ ) that bind to vascular endothelial cells including those of Schlemm's canal (Herrnberger et al. 2012). Both at P15 (Fig. 5i-1) and in the adult eye (Fig. $5 \mathrm{~m}-\mathrm{p}$ ), cells of the trabecular meshwork adjacent to the inner site of Schlemm's canal showed intense immunoreactivity. In addition, some cells in the inner wall endothelium of Schlemm's canal were positively labeled (Fig. 5i-p).

\section{Ccn2/Ctgf expression in the posterior eye}

At E16.5 and P1 $\beta$-galactosidase labeling was observed in the developing choroid and sclera, while the retinal pigment epithelium and the sensory retina were negative (Fig. 6a, b). At P5-positive staining became detectable in the neuroblastic layer of the developing sensory retina and, albeit with weaker intensity, in the ganglion cell layer (Fig. 6c). Staining of the ganglion cell and of the inner nuclear layer became more distinct at P10 (Fig. 6d). An intense signal was observed in both layers at P15 and in adulthood (Fig. 6e, f). From that time on until adulthood, staining was seen in the inner and outer plexiform layers (Fig. 6e, f). Positive staining in the choroid was seen through all postnatal stages until adulthood (Fig. 6b-f). To obtain more information on the specific cell type that expresses $\beta$-galactosidase in the ganglion cell and inner nuclear layer, we immunostained retinal flat mounts of $C T G F^{L a c Z /+}$ mice with antibodies against $\beta$-galactosidase and investigated a vertical view of $3 \mathrm{D}$ reconstructions of z-stacks through the entire retina (Fig. 6g-i). Again, we observed intense immunolabeling in ganglion cell layer and inner nuclear layer corroborating our findings obtained through X-gal staining. When analyzing individual stacks in the ganglion cell layer in a horizontal view, we identified positively labelled cells with cellular processes that were in contact with vessels on the retinal surface and very likely represented astrocytes (Fig. 6i). In contrast, cells in the inner nuclear layer had no obvious association with retinal capillaries (Fig. 6h). Next, we analyzed meridional sections through the retina that were again immunostained for $\beta$-galactosidase. Comparable to findings obtained with $X$-gal staining, immunoreactivity was seen in inner and outer plexiform layer, inner nuclear layer and ganglion cell layer. Double-immunostaining with antibodies against GFAP to visualize astrocytes on the retinal surface distinctly overlapped with $\beta$-galactosidase immunoreactivity and supported our assumption that retinal astrocytes express Ccn2/Ctgf (Fig. 7a-f). Next, double-immunostaining with antibodies against glutamine synthetase (GS) to stain Müller cells and $\beta$-galactosidase were performed, which showed a clear Ccn2/Ctgf expression in Müller cell processes and endfeet (Fig. 7g-1). Furthermore, we observed some scattered $\beta$-galactosidase-positive cells scattered in the ganglion cell layer and in the inner nuclear layer, which were negative for GS and GFAP. The localization and appearance of the cells matched with the description of displaced amacrine cells. The majority of displaced amacrine cells are starburst amacrine cells (Perez De Sevilla Muller et al. 2007), which is why we performed double-immunohistochemistry with antibodies against choline acetyltransferase (ChAT), a specific marker for starburst amacrine cells and against $\beta$-galactosidase. As expected, ChAT-immunoreactive somata were localized to the inner portion of the inner nuclear layer and the outer border of the inner plexiform layer, both at P15 and in adulthood (Fig. $7 \mathrm{~m}-\mathrm{r}$ ). Positive staining for $\beta$-galactosidase was seen in their perinuclear cytoplasm (Fig. 7m-r). Finally, we performed double-immunohistochemistry for $\beta$-galactosidase and CD31 to identify that endothelial cells of choroidal and retinal vessels homogenously express $\mathrm{Ccn} 2 /$ $\operatorname{Ctg} f($ Fig. $7 \mathrm{~s}-\mathrm{x})$.

\section{Ccn2/Ctgf expression in the optic nerve}

Until P1, the optic nerve and the optic nerve head remained unstained for $\beta$-galactosidase, with the exception of the hyaloid artery and its surrounding meninges that were positively labeled (Fig. 8b, c). At P5, positive labeling for $\beta$-galactosidase could be observed in the glial lamina of the optic nerve head. The staining was very intense at P10 and remained so until adulthood (Fig. 8e-h). In addition, from P5 
a

b c

RPE

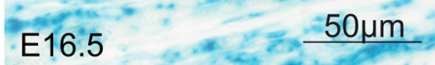

d

$\mathrm{GCL}$

INL

ONL

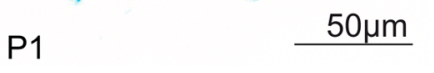

e

$\mathrm{NL}$

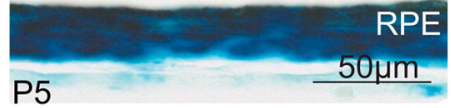

$\mathrm{f} \mathrm{C}^{*}+\mathrm{t}+\mathrm{z}$ -

GCL

INL

ONL

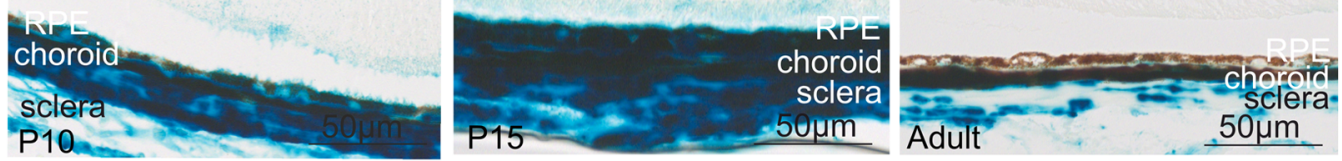

$\mathrm{g}$
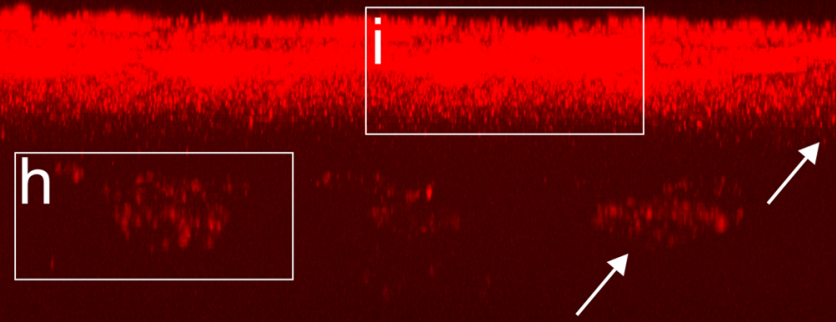

$20 \mu \mathrm{m}$

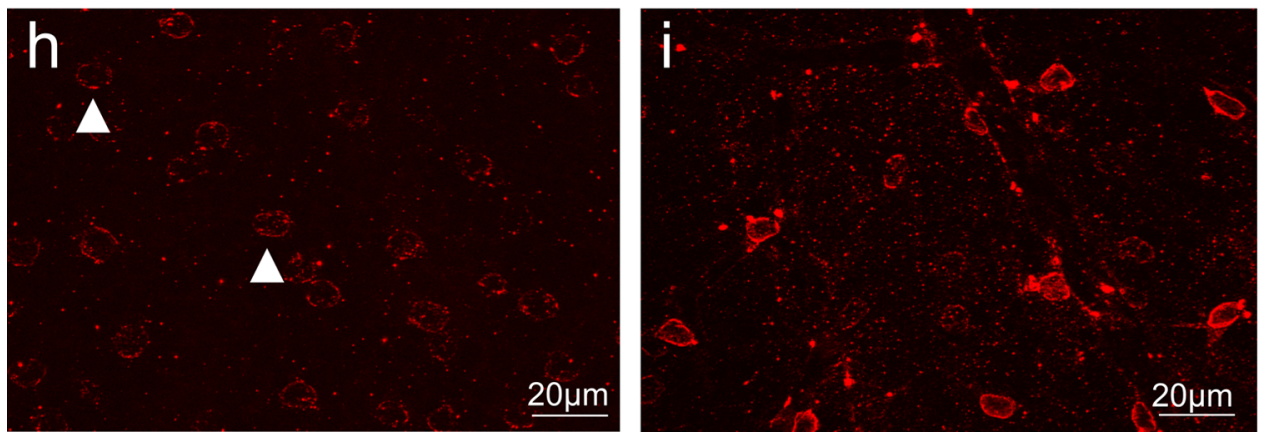


4Fig. 6 Ccn2/Ctgf promotor activity in the retina of $C T G F^{L a c Z /+}$ mice. a-f Histological staining of $\beta$-galactosidase activity of the retina from E16.5 to adulthood. A distinct staining of individual cells in the sensory retina is apparent at P10 and increases in intensity and extent until adulthood. GCL ganglion cell layer, INL inner nuclear layer, ONL outer nuclear layer, RPE retinal pigmented epithelium. $\mathbf{g}-\mathbf{i}$ Immunohistochemical staining against $\beta$-galactosidase (red) of a retinal flat mount of $C T G F^{\mathrm{LacZ} /+}$ mice, represented in a vertical view of the $3 \mathrm{D}$ reconstruction of $\mathrm{z}$-stacks through the entire retina. i Single recording of the ganglion cell layer shows the staining against $\beta$-galactosidase (red) in the vessels of the superficial plexus and adjacent cells (arrow). h Single recording of the inner nuclear layer identifies another cell type (arrowhead) with immunoreactivity against $\beta$-galactosidase (red). $n \geq 3$

until adulthood there was positive labeling of the optic nerve head prelaminar region albeit with less intensity than in the glial lamina (Fig. 8d-h). At P15, several distinct spots were intensively labeled in the postlaminar region of the optic nerve (Fig. 8f), a staining pattern that was less prominent at P20 and in the adult optic nerve. To identify the cellular origin of $C c n 2 / C t g f$ promoter activity at the optic nerve head, we performed double-immunohistochemistry with antibodies against both $\beta$-galactosidase and GFAP which is highly expressed in astrocytes of the mouse glial lamina (Howell et al. 2007; Sun et al. 2009). Immunoreactivity for $\beta$-galactosidase and GFAP was weak in the postlaminar region of the $\mathrm{P} 15$ optic nerve but more intense in the posterior part of the glial lamina (Fig. 9a-d). In the anterior glial lamina, there was intense immunoreactivity for $\beta$-galactosidase corroborating the findings seen with $\mathrm{X}$-gal staining (Fig. 9c, d). Higher magnification showed a close association and partial overlapping with GFAP labelled astrocytes. We attributed lack of complete overlap to the different intracellular location of GFAP-positive intermediate filaments and perinuclear $\beta$-galactosidase. The staining pattern in the adult optic nerve head was essentially similar to that seen in P15 (Fig. 9e-h).

\section{Discussion}

We conclude that CCN2/CTGF signaling is involved in the processes that govern neural crest (NC) morphogenesis during late embryonic and postnatal eye development. In the adult eye, it primarily contributes to functional processes in the trabecular meshwork outflow pathways, the choroidal and retinal vasculature, and the optic nerve head. This conclusion rests on our observation of (1) Ccn2/ Ctgf promoter activity in NC-derived cells differentiating to uveal and corneal tissues, and (2) persistent strong promoter activity in trabecular meshwork, endothelial cells of Schlemm's canal, retinal and choroidal vessels, and astrocytes of the optic nerve head glial lamina.
$\mathrm{NC}$ cells migrate to the developing eye to form the corneal stroma and endothelium, and later during a second migration wave the stroma of choroid, iris and ciliary body, and the trabecular meshwork (Cvekl and Tamm 2004). NC migration in cranial development is under control of a variety of transcription factors that initiate distinct signaling processes to guide NC migration and differentiation. There is substantial evidence obtained from studies of a variety of induced mutant mouse strains that members of the TGF- $\beta$ superfamily play a critical role in those signaling processes (Conway and Kaartinen 2011; Oka et al. 2007). The same appears to be the case for $\mathrm{NC}$ cells that are involved in eye development as both deficiency in TGF- $\beta$ (Iwao et al. 2009; Saika et al. 2001; Sanford et al. 1997) or BMP4 signaling (Chang et al. 2001), or overexpression of TGF- $\beta$ signaling (Flügel-Koch et al. 2002) interfere with NC-derived ocular morphogenesis. The welldocumented amplifying activity of CCN2/CTGF on TGF- $\beta$ signaling (Abreu et al. 2002; Gressner et al. 2009; Khankan et al. 2011; Mori et al. 1999) may well be involved in the action of TGF- $\beta$ signaling on cranial NC development. In support of this assumption are observations that CCN2/CTGF can rescue the phenotype caused by deficient TGF- $\beta$ signaling in the developing cranial $\mathrm{NC}$ such as the formation of mandibular dysgenesis or cleft palate (Oka et al. 2007), or causes similar defects when deleted (Ivkovic et al. 2003; Lambi et al. 2012; Tarr et al. 2017). Since our findings show high Ccn2/Ctgf expression in ocular NC cells, it is tempting to speculate that it plays a similarly important role to modulate $\mathrm{NC}$ morphogenesis during eye development. The availability of CCN2/CTGF during those critical processes in eye development may not exclusively depend on autocrine secretion by NC cells. In contrast, it may well be supported by adjacent paracrine sources as we also detected $C c n 2 / C t g f$ promoter activity in immediately adjacent cells of non-NC origin such as lens epithelium or pigmented ciliary epithelium.

We observed that the Ccn2/Ctgf promoter activity in NC-derived ocular tissues might be depended on developmental stages. In the adult eyes, the Ccn2/Ctgf promoter activity remained mainly detectable in the trabecular meshwork and the adjacent limbus. This observation agrees with data obtained through the NEIBank sequence tag analysis that identified $C \mathrm{cn} 2 / \mathrm{Ctg} f$ as one of the highest expressed genes in the human trabecular meshwork (Tomarev et al. 2003). We showed in previous work that CCN2/CTGF is critically required for actin stress fiber formation and contractility of trabecular meshwork cells and is simultaneously involved in the modulation of their ECM deposition (Junglas et al. 2012, 2009; Kuespert et al. 2015). Since both processes are critically involved in generating and modulating aqueous humor outflow resistance (Stamer et al. 2015; Tamm et al. 2015), the continuous high promoter activity of Ccn2/Ctgf in the mouse eye is not necessarily surprising. An interesting new 

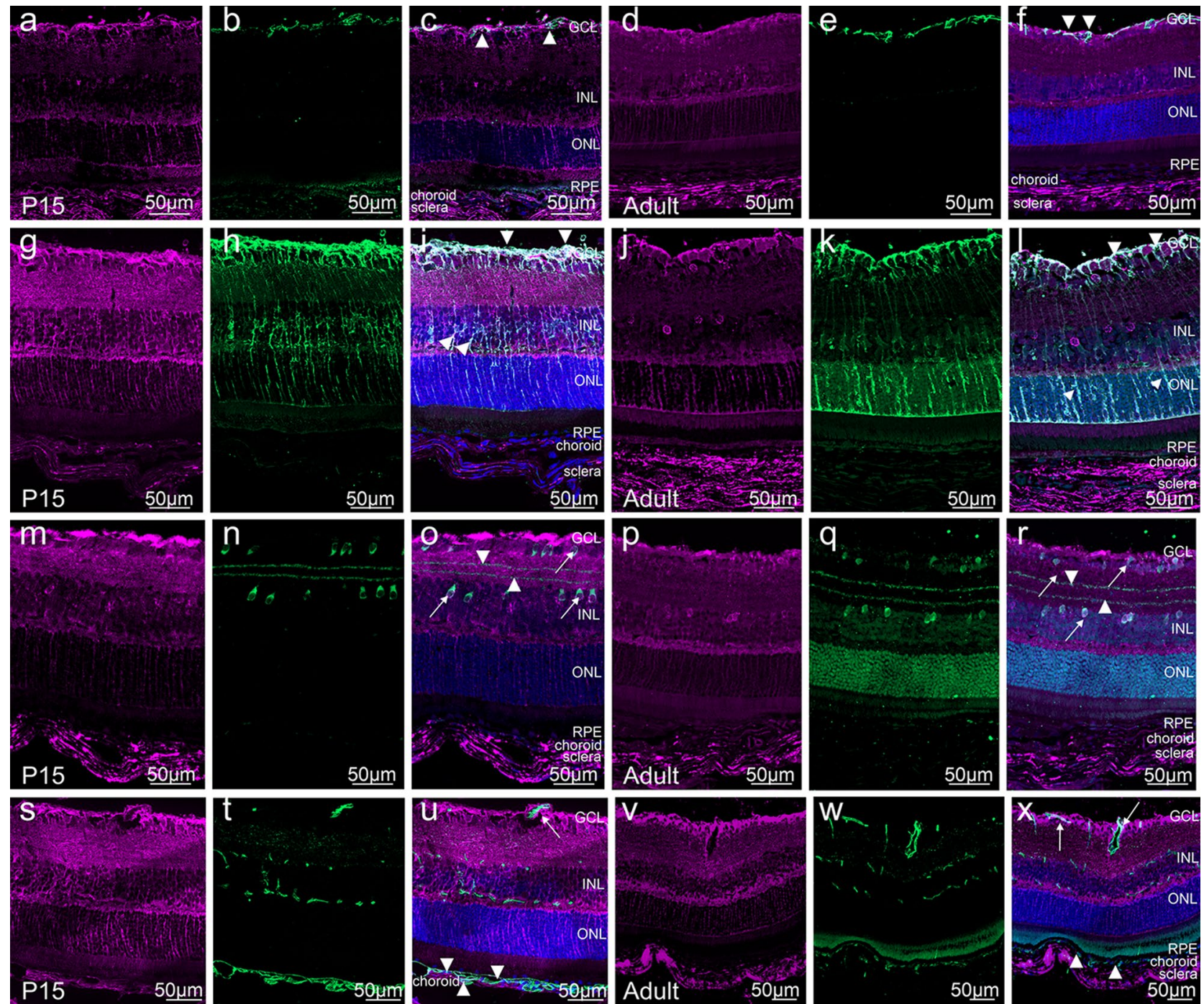

Fig. 7 Cell type specific $C c n 2 / C t g f$ promotor activity in the retina of $C T G F^{\mathrm{LacZ} /+}$ mice. Immunohistochemical staining against $\beta$-galactosidase (purple) and different retinal cell type markers (green). a-f Double-immunohistochemistry against $\beta$-galactosidase and GFAP shows weak immunoreactivity for $\beta$-galactosidase in retinal astrocytes (arrowhead) on P15 or adulthood. g-l Doubleimmunohistochemistry against $\beta$-galactosidase and glutamine synthetase (GS) shows an intense colocalization in the Müller cells processes (lower arrowheads) and endfeet (upper arrowheads) at P15 and in the adult retina. $\mathbf{m}-\mathbf{r}$ Double-immunohistochemistry against $\beta$-galactosidase and choline acetyltransferase (ChAT) shows colo-

aspect of our study is that we were able to show promoter activity in Schlemm's canal cells in situ corroborating data from previous in vitro studies (Overby et al. 2014).

Schlemm's canal cells are not the only type of vascular endothelial cells in the eye that display $\operatorname{Ccn} 2 / \operatorname{Ctg} f$ promoter activity as our data show that the same is the case for retinal and choroidal endothelial cells. Ccn2/Ctgf promoter activity or mRNA expression has also been shown for developing and adult vascular endothelial cells of other organs calization of $\beta$-galactosidase in starburst amacrine cells in the INL (arrow) and displaced starburst amacrine cells in the GCL (arrow) at P15 and in the adult retina. $\mathbf{s}-\mathbf{x}$ Double-immunohistochemistry against $\beta$-galactosidase and CD31. CD31 immunoreactivity identifies the endothelial cells of the three retinal vascular plexus and the choriocapillaris. $\beta$-Galactosidase immunoreactivity is seen in the endothelial cells of the retinal plexus (arrow) and choroidal vasculature (arrowhead) in the P15 and adult retina. GCL ganglion cell layer, INL inner nuclear layer, ONL outer nuclear layer, RPE retinal pigmented epithelium, $\beta$-Gal $\beta$-galactosidase. Nuclei were stained with DAPI. $n \geq 3$

(Friedrichsen et al. 2005, 2003; Hall-Glenn et al. 2012). Our findings in the eye agree with those of $\mathrm{Pi}$ and colleagues (Pi et al. 2011) who observed CCN2/CTGF immunostaining in retinal vascular endothelial cells and pericytes during retinal angiogenesis. In addition, the authors showed that $\mathrm{CCN} 2 /$ CTGF is critically required for retinal angiogenesis, since the injection of antibodies against CCN2/CTGF into the vitreous of $\mathrm{P} 2$ mice resulted in a decrease of the superficial retinal vascular plexus. The continuous promoter activity of 


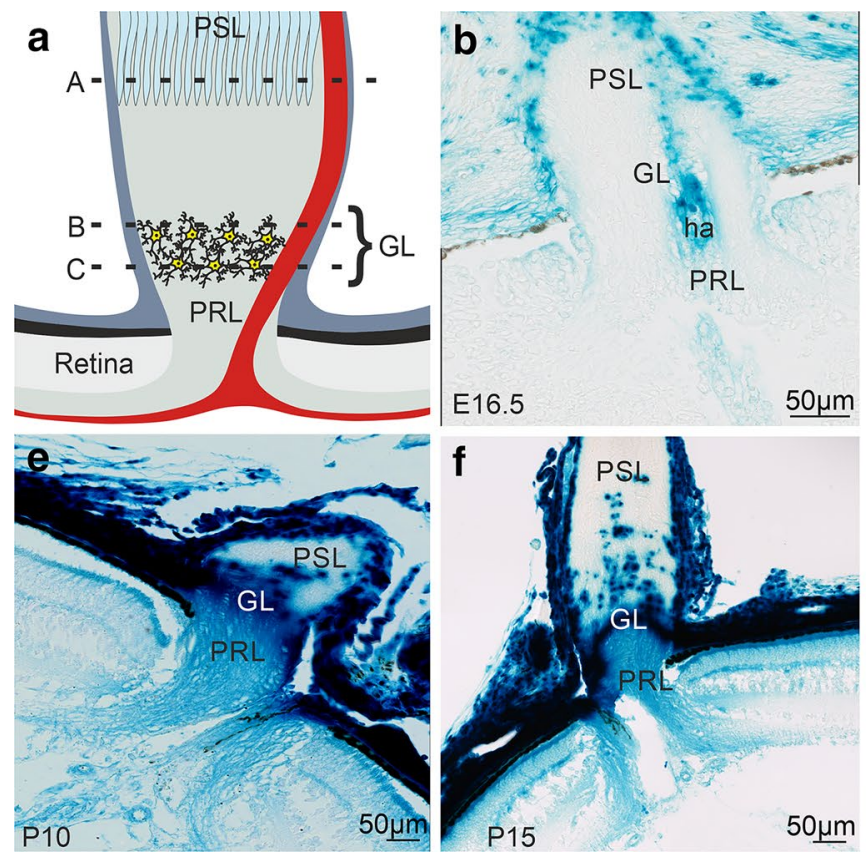

Fig. 8 C cn2/Ctgf promotor activity in the optic nerve of $C T G F^{\text {LacZ/+ }}$ mice. a Schematic of the optic nerve head showing the major elements in this region. Different positions indicated with A-C depict represent the positions where cross sections were performed shown in Fig. 9. b At E16.5, the meninges of the developing optic nerve and the cells of the hyaloid artery show positive staining of $\beta$-galactosidase activity. c At P1, a similar staining pattern is seen. d

Ccn2/Ctgf in the adult mouse eye agrees with data obtained by immunohistochemistry of human eyes (van Setten et al. 2016) and strongly indicates a function for the adult eyes that is beyond angiogenesis in retinal development. A potential function could be related to the observation that Ccn2/Ctgf expression is upregulated by vascular endothelial growth factor (VEGF) (He et al. 2003; Suzuma et al. 2000) and its known inhibiting role of VEGF-induced angiogenesis by formation of VEGF-CTGF complexes (Inoki et al. 2002; Jang et al. 2004). The continuous expression of CCN2/ CTGF in adult retinal vessel might be useful to antagonize signaling processes that have the potential to cause retinal neovascularization and its associated adverse effects on retinal structure and function. An additional paracrine expression of $\mathrm{Ccn} 2 / \mathrm{Ctg} f$ in perivascular astrocytes on the retinal surface may well contribute to this function. Quite similarly Müller cell-derived CCN2/CTGF likely antagonizes a VEGF-induced growth signal on intraretinal capillaries while the continuous Ccn2/Ctgf expression in adult choroidal vessels likely contributes to prevent choroidal neovascularization. Overall, the TGF- $\beta$ amplifying function of CCN2/CTGF is likely to contribute to its effects on retinal and choroidal vessels as lack of TGF- $\beta$ signaling in the eye causes retinal and choroidal neovascularization
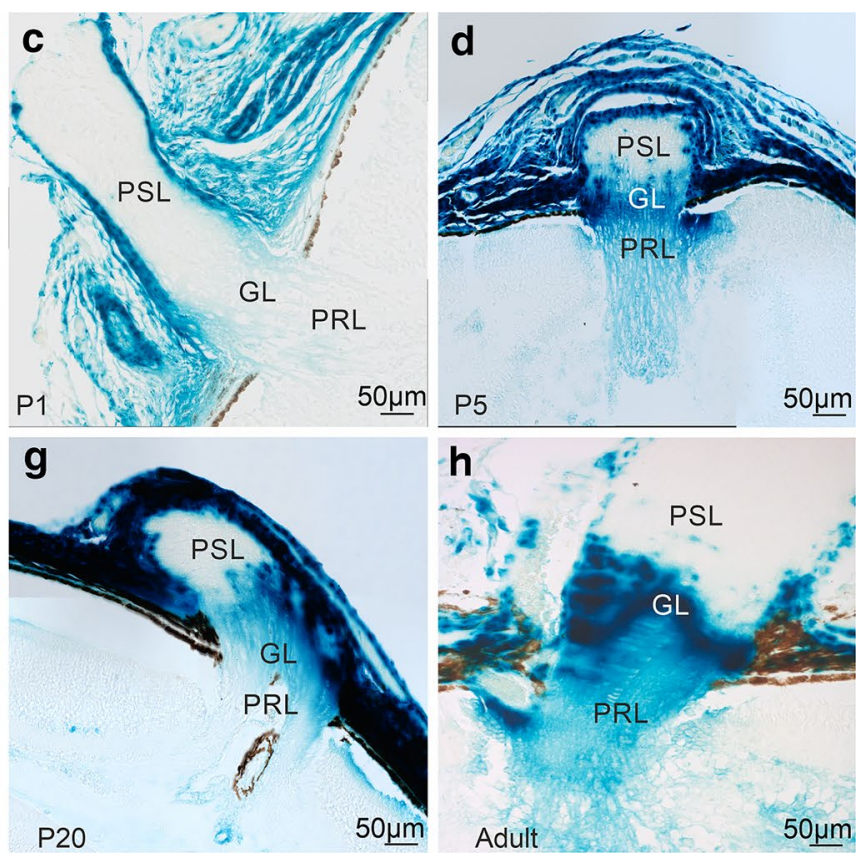

At P5, a distinct labeling at the optic nerve head that corresponds to the site of the developing glial lamina is observed. e-h From P10 to adulthood, an intense staining of the glial lamina and a weaker signal in the prelaminar region is present. At P15, several distinct spots are intensively labeled in the postlaminar region of the optic nerve. PSL postlaminar region, GL glial lamina, PRL prelaminar region, ha hyaloid artery. $n \geq 3$

that finally destroys retinal structure and function (Braunger et al. 2015b; Schlecht et al. 2017).

An unexpected finding was the very high expression of $C c n 2 / C \operatorname{tg} f$ in the glial lamina of the mouse optic nerve head. This area is equivalent to the Lamina cribrosa in the primate eye (Stowell et al. 2017; Tamm et al. 2017) and contains a dense network of intertwined astrocytes that constitutively express GFAP and show other similarities to white matter fibrous astrocytes (Sun et al. 2009). Unlike their counterpart in the brain, astrocytes in the mouse glial lamina are under a substantial and continuous mechanical strain induced by intraocular pressure (IOP) as are the astrocytes in the Lamina cribrosa of the primate eye. IOP is the most critical risk factor for damage of axons at the optic nerve head in glaucoma, both in the primate and the mouse eye (Quigley 2011; Steinhart et al. 2014; Weinreb et al. 2014). Experimental data indicate a rapid reorganization of glial lamina astrocytes and their processes in response to brief and mild elevations of IOP (Sun et al. 2013). A signaling factor like CCN2/CTGF that is known to modulate the actin cytoskeleton and the synthesis of fibrillar ECM components that are connected via integrins may be an essential requirement for quick astrocyte reorganization in response to mechanical stimuli. 
Fig. 9 Cell type specific Ccn2/ Ctgf promotor activity in the optic nerve of $C T G F^{\text {LacZ/+ }}$ mice. a, e Double-immunohistochemical staining against $\beta$-galactosidase (purple) and GFAP (green) on sagittal sections of the optic nerve at P15 a and adult mouse eye e. $\beta$-Galactosidase immunoreactivity is seen in region of the glial lamina and the prelaminar region that colocalizes with GFAP positive astrocytes (higher magnification arrowhead). Dotted line in enlarged merged image represents the region of the glial lamina. b-d, f-h Double-immunohistochemical staining against $\beta$-galactosidase and GFAP on cross sections of the optic nerve at P15 and the adult mouse eye. Schematic in Fig. 8a depicts the different positions $(\mathrm{A}-\mathrm{C})$, where sections were performed within the optic nerve. $\mathbf{b}, \mathbf{f}$ In position A, the postlaminar, myelinated region of the optic nerve is seen in cross section. Immunoreactivity for $\beta$-galactosidase and GFAP is weak in the postlaminar region in the optic nerve. Position B c, $\mathbf{g}$ and $\mathrm{C}$ $\mathbf{d}, \mathbf{h}$ localization of cross sections through the glial lamina. Double-immunostaining shows a close association and partial overlapping of $\beta$-galactosidase with GFAP-labelled astrocytes (higher magnification arrowhead). Nuclei were stained with DAPI. $n \geq 3$
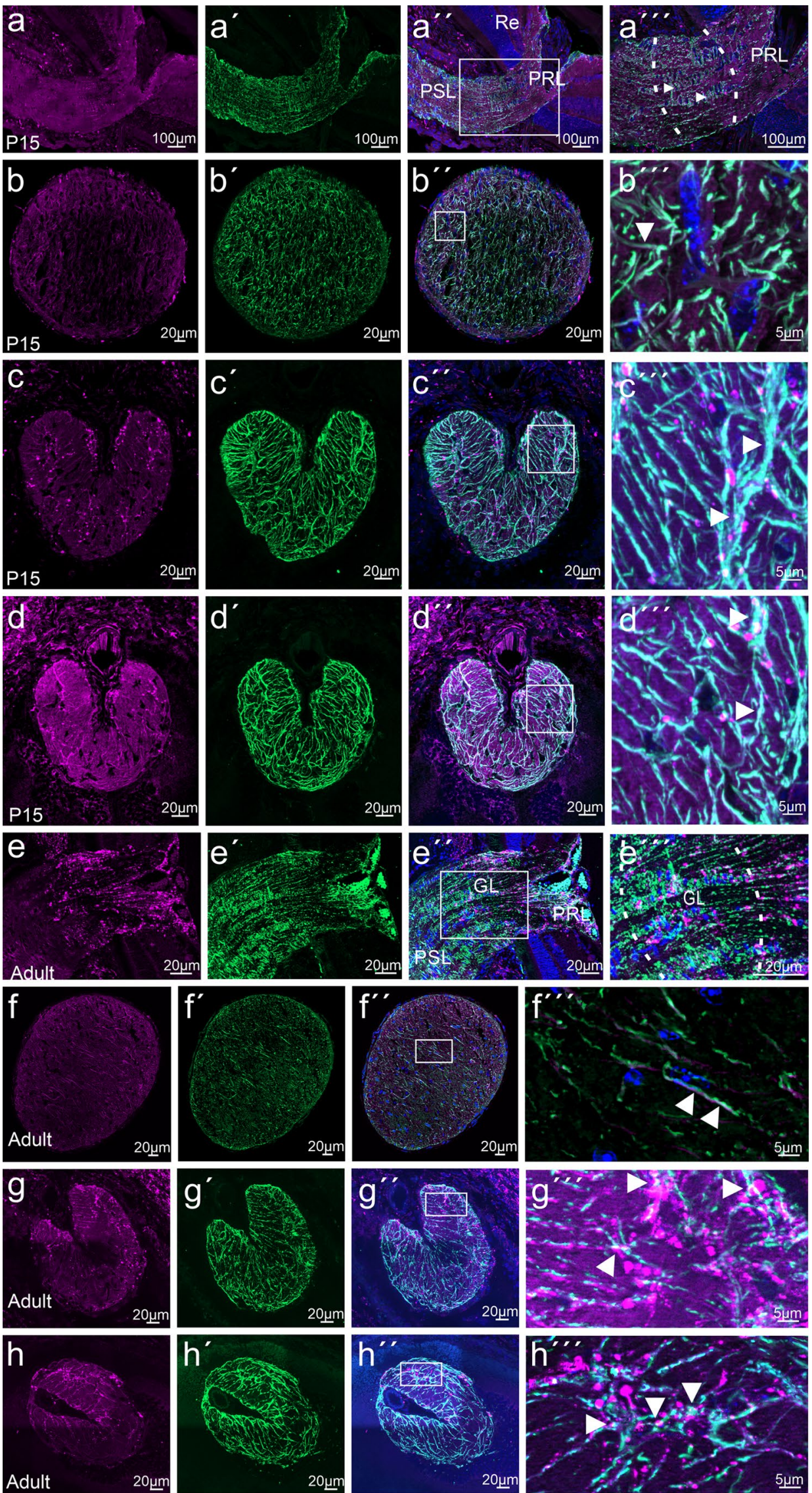
In support of this assumption, we observed the promoter activity in the cornea and sclera only during development, which might be necessary to build up the ECM of these load-bearing structures. The slow ECM turnover in the cornea and sclera in the adult tissues might not require CCN2/CTGF activity under normal conditions. In contrast, in tissues that are subject to continuous microstrain, CCN2/CTGF might be induced through mechanical stimuli. This scenario likely involves activation of mechanotransducing proteins such as YAP and TAZ, which were both identified in human trabecular meshwork cells and in fibroblasts (Chudgar et al. 2006; Guo et al. 2011; Schild and Trueb 2002; Thomasy et al. 2013). There is substantial evidence that CCN2/CTGF inhibits oligodendrocyte differentiation in vitro and in vivo (Lamond and Barnett 2013; Stritt et al. 2009). In the brain, it is neuronal-derived CCN2/CTGF that acts negatively on myelination (Ercan, et al. 2017). It is tempting to speculate that in the optic nerve head, the local high amounts of astrocyte-derived CCN2/CTGF inhibit myelination of the optic nerve axons that pass through the glial lamina and that the lack of myelination increases their vulnerability to mechanical strain induced by intraocular pressure. Further studies using mice with an induced conditional deletion of Ccn2/Ctgf appear to be the appropriate tool to shed light on the distinct functional role(s) of Ccn2/Ctgf in the glial lamina of the optic nerve head.

Acknowledgments We thank Maureen Gannon (Vanderbilt University Medical Center) for generously providing us with $C T G F^{\mathrm{LacZ/+}}$-breeding couples and Elke Stauber and Angelika Pach (Institute of Human Anatomy and Embryology, University of Regensburg) for excellent technical assistance.

Author contributions Andrea E. Dillinger and Sabrina Kuespert: conducting experiments and manuscript preparation. Franziska Froemel: conducting experiments. Ernst R. Tamm: manuscript preparation. Rudolf Fuchshofer: planning and conducting experiments; manuscript preparation.

Funding Open Access funding enabled and organized by Projekt DEAL. Deutsche Forschungsgemeinschaft (FU734/6-1).

\section{Compliance with ethical standards}

Conflict of interest The authors declare that they have no conflict of interest.

Ethical approval All experiments conformed to the tenets of the National Institutes of Health Guidelines on the Care and Use of Animals in Research, the EU Directive 2010/63/E and the Association for Research in Vision and Ophthalmology Statement for the Use of Animals in Ophthalmic in Vision Research, and were approved by local authorities (permit ID: 54-2532.1-44/12; committee: Regierung Oberpfalz, Bavaria, Germany).

Informed consent None. No data of patients were included in the manuscript.
Open Access This article is licensed under a Creative Commons Attribution 4.0 International License, which permits use, sharing, adaptation, distribution and reproduction in any medium or format, as long as you give appropriate credit to the original author(s) and the source, provide a link to the Creative Commons licence, and indicate if changes were made. The images or other third party material in this article are included in the article's Creative Commons licence, unless indicated otherwise in a credit line to the material. If material is not included in the article's Creative Commons licence and your intended use is not permitted by statutory regulation or exceeds the permitted use, you will need to obtain permission directly from the copyright holder. To view a copy of this licence, visit http://creativecommons.org/licenses/by/4.0/.

\section{References}

Abreu JG, Ketpura NI, Reversade B, De Robertis EM (2002) Connective-tissue growth factor (CTGF) modulates cell signalling by BMP and TGF-beta. Nat Cell Biol 4:599-604

Bochaton-Piallat ML, Gabbiani G, Hinz B (2016) The myofibroblast in wound healing and fibrosis: answered and unanswered questions. F1000Res 5:752

Braunger BM, Fuchshofer R, Tamm ER (2015) The aqueous humor outflow pathways in glaucoma: a unifying concept of disease mechanisms and causative treatment. Eur J Pharm Biopharm 95:173-181

Braunger BM, Leimbeck SV, Schlecht A, Volz C, Jagle H, Tamm ER (2015) Deletion of ocular transforming growth factor beta signaling mimics essential characteristics of diabetic retinopathy. Am J Pathol 185:1749-1768

Brigstock DR (2003) The CCN family: a new stimulus package. J Endocrinol 178:169-175

Browne JG, Ho SL, Kane R, Oliver N, Clark AF, O'Brien CJ, Crean JK (2011) Connective tissue growth factor is increased in pseudoexfoliation glaucoma. Invest Ophthalmol Vis Sci 52:3660-3666

Carthy JM (2018) TGFbeta signaling and the control of myofibroblast differentiation: implications for chronic inflammatory disorders. J Cell Physiol 233:98-106

Chang B, Smith RS, Peters M, Savinova OV, Hawes NL, Zabaleta A, Nusinowitz S, Martin JE, Davisson ML, Cepko CL, Hogan BL, John SW (2001) Haploinsufficient Bmp4 ocular phenotypes include anterior segment dysgenesis with elevated intraocular pressure. BMC Genet 2:18

Chudgar SM, Deng P, Maddala R, Epstein DL, Rao PV (2006) Regulation of connective tissue growth factor expression in the aqueous humor outflow pathway. Mol Vis 12:1117-1126

Conway SJ, Kaartinen V (2011) TGFbeta superfamily signaling in the neural crest lineage. Cell Adh Migr 5:232-236

Crawford LA, Guney MA, Oh YA, Deyoung RA, Valenzuela DM, Murphy AJ, Yancopoulos GD, Lyons KM, Brigstock DR, Economides A, Gannon M (2009) Connective tissue growth factor (CTGF) inactivation leads to defects in islet cell lineage allocation and beta-cell proliferation during embryogenesis. Mol Endocrinol 23:324-336

Cvekl A, Tamm ER (2004) Anterior eye development and ocular mesenchyme: new insights from mouse models and human diseases. BioEssays 26:374-386

Ercan E, Han JM, Di Nardo A, Winden K, Han MJ, Hoyo L, Saffari A, Leask A, Geschwind DH, Sahin M (2017) Neuronal CTGF/ CCN2 negatively regulates myelination in a mouse model of tuberous sclerosis complex. J Exp Med 214:681-697

Flügel-Koch C, Ohlmann A, Piatigorsky J, Tamm ER (2002) Disruption of anterior segment development by TGF-beta1 overexpression in the eyes of transgenic mice. Dev Dyn 225:111-125

Friedrichsen S, Heuer H, Christ S, Cuthill D, Bauer K, Raivich G (2005) Gene expression of connective tissue growth factor in adult mouse. Growth Factors 23:43-53 
Friedrichsen S, Heuer H, Christ S, Winckler M, Brauer D, Bauer K, Raivich G (2003) CTGF expression during mouse embryonic development. Cell Tissue Res 312:175-188

Fuchshofer R, Stephan DA, Russell P, Tamm ER (2009) Gene expression profiling of TGFbeta2- and/or BMP7-treated trabecular meshwork cells: Identification of Smad7 as a critical inhibitor of TGF-beta2 signaling. Exp Eye Res 88:1020-1032

Fuchshofer R, Ullmann S, Zeilbeck LF, Baumann M, Junglas B, Tamm ER (2011) Connective tissue growth factor modulates podocyte actin cytoskeleton and extracellular matrix synthesis and is induced in podocytes upon injury. Histochem Cell Biol 136:301-319

Fuchshofer R, Yu AH, Welge-Lüssen U, Tamm ER (2007) Bone morphogenetic protein-7 is an antagonist of transforming growth factor-beta2 in human trabecular meshwork cells. Invest Ophthalmol Vis Sci 48:715-726

Gressner OA, Gressner AM (2008) Connective tissue growth factor: a fibrogenic master switch in fibrotic liver diseases. Liver Int 28:1065-1079

Gressner OA, Lahme B, Siluschek M, Rehbein K, Weiskirchen R, Gressner AM (2009) Connective tissue growth factor is a Smad2 regulated amplifier of transforming growth factor beta actions in hepatocytes - but without modulating bone morphogenetic protein 7 signaling. Hepatology 49:2021-2030

Grotendorst GR, Okochi H, Hayashi N (1996) A novel transforming growth factor beta response element controls the expression of the connective tissue growth factor gene. Cell Growth Differ 7:469-480

Guo F, Carter DE, Leask A (2011) Mechanical tension increases $\mathrm{CCN} 2 / \mathrm{CTGF}$ expression and proliferation in gingival fibroblasts via a TGFbeta-dependent mechanism. PLoS ONE 6:e19756

Hall-Glenn F, De Young RA, Huang BL, van Handel B, Hofmann JJ, Chen TT, Choi A, Ong JR, Benya PD, Mikkola H, Iruela-Arispe ML, Lyons KM (2012) CCN2/connective tissue growth factor is essential for pericyte adhesion and endothelial basement membrane formation during angiogenesis. PLoS ONE 7:e30562

He S, Jin ML, Worpel V, Hinton DR (2003) A role for connective tissue growth factor in the pathogenesis of choroidal neovascularization. Arch Ophthalmol 121:1283-1288

Herrnberger L, Ebner K, Junglas B, Tamm ER (2012) The role of plasmalemma vesicle-associated protein (PLVAP) in endothelial cells of Schlemm's canal and ocular capillaries. Exp Eye Res 105:27-33

Hinz B, Phan SH, Thannickal VJ, Galli A, Bochaton-Piallat ML, Gabbiani G (2007) The myofibroblast: one function, multiple origins. Am J Pathol 170:1807-1816

Hinz B, Phan SH, Thannickal VJ, Prunotto M, Desmouliere A, Varga J, De Wever O, Mareel M, Gabbiani G (2012) Recent developments in myofibroblast biology: paradigms for connective tissue remodeling. Am J Pathol 180:1340-1355

Ho LTY, Osterwald A, Ruf I, Hunziker D, Mattei P, Challa P, Vann R, Ullmer C, Rao PV (2020) Role of the autotaxin-lysophosphatidic acid axis in glaucoma, aqueous humor drainage and fibrogenic activity. Biochim Biophys Acta Mol Basis Dis 1866:165560

Holmes A, Abraham DJ, Sa S, Shiwen X, Black CM, Leask A (2001) CTGF and SMADs, maintenance of scleroderma phenotype is independent of SMAD signaling. J Biol Chem 276:10594-10601

Howell GR, Libby RT, Jakobs TC, Smith RS, Phalan FC, Barter JW, Barbay JM, Marchant JK, Mahesh N, Porciatti V, Whitmore AV, Masland RH, John SW (2007) Axons of retinal ganglion cells are insulted in the optic nerve early in DBA/2J glaucoma. J Cell Biol 179:1523-1537

Igarashi A, Okochi H, Bradham DM, Grotendorst GR (1993) Regulation of connective tissue growth factor gene expression in human skin fibroblasts and during wound repair. Mol Biol Cell 4:637-645

Inoki I, Shiomi T, Hashimoto G, Enomoto H, Nakamura H, Makino K, Ikeda E, Takata S, Kobayashi K, Okada Y (2002) Connective tissue growth factor binds vascular endothelial growth factor (VEGF) and inhibits VEGF-induced angiogenesis. FASEB J 16:219-221
Ivkovic S, Yoon BS, Popoff SN, Safadi FF, Libuda DE, Stephenson RC, Daluiski A, Lyons KM (2003) Connective tissue growth factor coordinates chondrogenesis and angiogenesis during skeletal development. Development 130:2779-2791

Iwao K, Inatani M, Matsumoto Y, Ogata-Iwao M, Takihara Y, Irie F, Yamaguchi Y, Okinami S, Tanihara H (2009) Heparan sulfate deficiency leads to Peters anomaly in mice by disturbing neural crest TGF-beta2 signaling. J Clin Invest 119:1997-2008

Jang HS, Kim HJ, Kim JM, Lee YS, Kim KL, Kim JA, Lee JY, Suh W, Choi JH, Jeon ES, Byun J, Kim DK (2004) A novel ex vivo angiogenesis assay based on electroporation-mediated delivery of naked plasmid DNA to skeletal muscle. Mol Ther 9:464-474

Jun AS, Chakravarti S, Edelhauser HF, Kimos M (2006) Aging changes of mouse corneal endothelium and Descemet's membrane. Exp Eye Res 83:890-896

Junglas B, Kuespert S, Seleem AA, Struller T, Ullmann S, Bosl M, Bosserhoff A, Kostler J, Wagner R, Tamm ER, Fuchshofer $\mathrm{R}$ (2012) Connective tissue growth factor causes glaucoma by modifying the actin cytoskeleton of the trabecular meshwork. Am J Pathol 180:2386-2403

Junglas B, Yu AH, Welge-Lussen U, Tamm ER, Fuchshofer R (2009) Connective tissue growth factor induces extracellular matrix deposition in human trabecular meshwork cells. Exp Eye Res 88:1065-1075

Kapoor M, Liu S, Huh K, Parapuram S, Kennedy L, Leask A (2008) Connective tissue growth factor promoter activity in normal and wounded skin. Fibrogenesis \& Tissue Repair 1:3

Karnovsky MJ (1965) A formaldehyde-glutaraldehyde fixative of high osmolality for use in electron-microscopy. J Cell Biol 27:137e138

Khankan R, Oliver N, He S, Ryan SJ, Hinton DR (2011) Regulation of fibronectin-EDA through CTGF domain-specific interactions with TGFbeta2 and its receptor TGFbetaRII. Invest Ophthalmol Vis Sci 52:5068-5078

Kuespert S, Junglas B, Braunger BM, Tamm ER, Fuchshofer R (2015) The regulation of connective tissue growth factor expression influences the viability of human trabecular meshwork cells. J Cell Mol Med 20:1-11

Kuiper EJ, Roestenberg P, Ehlken C, Lambert V, van Treslong-de Groot HB, Lyons KM, Agostini H-JT, Rakic J-M, Klaassen I, Van Noorden CJF, Goldschmeding R, Schlingemann RO (2007) Angiogenesis is not impaired in connective tissue growth factor (CTGF) knock-out mice. The journal of histochemistry and cytochemistry : official journal of the Histochemistry Society 55:1139-1147

Kuiper EJ, van Zijderveld R, Roestenberg P, Lyons KM, Goldschmeding R, Klaassen I, Van Noorden CJF, Schlingemann RO (2008) Connective tissue growth factor is necessary for retinal capillary basal lamina thickening in diabetic mice. The journal of histochemistry and cytochemistry : official journal of the Histochemistry Society 56:785-792

Lambi AG, Pankratz TL, Mundy C, Gannon M, Barbe MF, Richtsmeier JT, Popoff SN (2012) The skeletal site-specific role of connective tissue growth factor in prenatal osteogenesis. Dev Dyn 241:1944-1959

Lamond R, Barnett SC (2013) Schwann cells but not olfactory ensheathing cells inhibit CNS myelination via the secretion of connective tissue growth factor. J Neurosci 33:18686-18697

Leask A (2020) Conjunction junction, what's the function? CCN proteins as targets in fibrosis and cancers. Am J Physiol Cell Physiol 318(6):C1046-C1054. https://doi.org/10.1152/ajpce 11.00028 .2020

Leask A, Sa S, Holmes A, Shiwen X, Black CM, Abraham DJ (2001) The control of ccn2 (ctgf) gene expression in normal and scleroderma fibroblasts. Mol Pathol 54:180-183

Liu S, Taghavi R, Leask A (2010) Connective tissue growth factor is induced in bleomycin-induced skin scleroderma. J Cell Commun Signal 4:25-30 
Mason RM (2013) Fell-Muir lecture: connective tissue growth factor (CCN2) - a pernicious and pleiotropic player in the development of kidney fibrosis. Int J Exp Pathol 94:1-16

Mori T, Kawara S, Shinozaki M, Hayashi N, Kakinuma T, Igarashi A, Takigawa M, Nakanishi T, Takehara K (1999) Role and interaction of connective tissue growth factor with transforming growth factor-beta in persistent fibrosis: a mouse fibrosis model. J Cell Physiol 181:153-159

Oka K, Oka S, Sasaki T, Ito Y, Bringas P Jr, Nonaka K, Chai Y (2007) The role of TGF-beta signaling in regulating chondrogenesis and osteogenesis during mandibular development. Dev Biol 303:391-404

Overby DR, Zhou EH, Vargas-Pinto R, Pedrigi RM, Fuchshofer R, Braakman ST, Gupta R, Perkumas KM, Sherwood JM, Vahabikashi A, Dang Q, Kim JH, Ethier CR, Stamer WD, Fredberg JJ, Johnson M (2014) Altered mechanobiology of Schlemm's canal endothelial cells in glaucoma. Proc Natl Acad Sci U S A 111:13876-13881

Perbal A, Perbal B (2016) The CCN family of proteins: a 25th anniversary picture. J Cell Commun Signal 10:177-190

Perbal B (2013) CCN proteins: a centralized communication network. J Cell Commun Signal 7:169-177

Perbal B (2018) The concept of the CCN protein family revisited: a centralized coordination network. J Cell Commun Signal 12:3-12

Perbal B, Tweedie S, Bruford E (2018) The official unified nomenclature adopted by the HGNC calls for the use of the acronyms, CCN1-6, and discontinuation in the use of CYR61, CTGF, NOV and WISP 1-3 respectively. J Cell Commun Signal 12:625-629

Perez De Sevilla Muller L, Shelley J, Weiler R (2007) Displaced amacrine cells of the mouse retina. J Comp Neurol 505:177-189

Pi L, Xia H, Liu J, Shenoy AK, Hauswirth WW, Scott EW (2011) Role of connective tissue growth factor in the retinal vasculature during development and ischemia. Invest Ophthalmol Vis Sci 52:8701-8710

Quigley HA (2011) Glaucoma Lancet 377:1367-1377

Reinehr S, Koch D, Weiss M, Froemel F, Voss C, Dick HB, Fuchshofer R, Joachim SC (2019) Loss of retinal ganglion cells in a new genetic mouse model for primary open-angle glaucoma. J Cell Mol Med 23:5497-5507

Richardson KC, Jarre, L, Finke H, (1960) Embedding in epoxy resins for ultrathin sectioning in electron microscopy. Stain Technol 35:313e323

Richeldi L, Fernandez Perez ER, Costabel U, Albera C, Lederer DJ, Flaherty KR, Ettinger N, Perez R, Scholand MB, Goldin J, Peony Yu KH, Neff T, Porter S, Zhong M, Gorina E, Kouchakji E, Raghu G (2020) Pamrevlumab, an anti-connective tissue growth factor therapy, for idiopathic pulmonary fibrosis (PRAISE): a phase 2, randomised, double-blind, placebo-controlled trial. Lancet Respir Med 8:25-33

Saika S, Liu CY, Azhar M, Sanford LP, Doetschman T, Gendron RL, Kao CW, Kao WW (2001) TGFbeta2 in corneal morphogenesis during mouse embryonic development. Dev Biol 240:419-432

Sanford LP, Ormsby I, Gittenberger-de Groot AC, Sariola H, Friedman R, Boivin GP, Cardell EL, Doetschman T (1997) TGFbeta2 knockout mice have multiple developmental defects that are non- overlapping with other TGFbeta knockout phenotypes. Development 124:2659-2670

Sato S, Nagaoka T, Hasegawa M, Tamatani T, Nakanishi T, Takigawa M, Takehara K (2000) Serum levels of connective tissue growth factor are elevated in patients with systemic sclerosis: association with extent of skin sclerosis and severity of pulmonary fibrosis. $\mathrm{J}$ Rheumatol 27:149-154

Schild C, Trueb B (2002) Mechanical stress is required for high-level expression of connective tissue growth factor. Exp Cell Res 274:83-91

Schlecht A, Leimbeck SV, Jägle H, Feuchtinger A, Tamm ER, Braunger BM (2017) Deletion of endothelial transforming growth factorbeta signaling leads to choroidal neovascularization. Am J Pathol $187: 2570-2589$
Stamer WD, Braakman ST, Zhou EH, Ethier CR, Fredberg JJ, Overby DR, Johnson M (2015) Biomechanics of Schlemm's canal endothelium and intraocular pressure reduction. Prog Retin Eye Res 44:86-98

Steinhart MR, Cone-Kimball E, Nguyen C, Nguyen TD, Pease ME, Chakravarti S, Oglesby EN, Quigley HA (2014) Susceptibility to glaucoma damage related to age and connective tissue mutations in mice. Exp Eye Res 119:54-60

Stowell C, Burgoyne CF, Tamm ER, Ethier CR, Participants LIIoAGN (2017) Biomechanical aspects of axonal damage in glaucoma: a brief review. Exp Eye Res 157:13-19

Stritt C, Stern S, Harting K, Manke T, Sinske D, Schwarz H, Vingron M, Nordheim A, Knoll B (2009) Paracrine control of oligodendrocyte differentiation by SRF-directed neuronal gene expression. Nat Neurosci 12:418-427

Sun D, Lye-Barthel M, Masland RH, Jakobs TC (2009) The morphology and spatial arrangement of astrocytes in the optic nerve head of the mouse. J Comp Neurol 516:1-19

Sun D, Qu J, Jakobs TC (2013) Reversible reactivity by optic nerve astrocytes. Glia 61:1218-1235

Suzuma K, Naruse K, Suzuma I, Takahara N, Ueki K, Aiello LP, King GL (2000) Vascular endothelial growth factor induces expression of connective tissue growth factor via KDR, Flt1, and phosphatidylinositol 3-kinase-akt-dependent pathways in retinal vascular cells. J Biol Chem 275:40725-40731

Tamm ER, Braunger BM, Fuchshofer R (2015) Intraocular pressure and the mechanisms involved in resistance of the aqueous humor flow in the trabecular meshwork outflow pathways. Prog Mol Biol Transl Sci 134:301-314

Tamm ER, Ethier CR, Participants LIIoAGN (2017) Biological aspects of axonal damage in glaucoma: a brief review. Exp Eye Res 157:5-12

Tarr JT, Visser TG, Moon JE, Hendesi H, Barbe MF, Bradley JP, Popoff SN (2017) The pivotal role of CCN2 in mammalian palatogenesis. J Cell Commun Signal 11:25-37

Thomasy SM, Morgan JT, Wood JA, Murphy CJ, Russell P (2013) Substratum stiffness and latrunculin $B$ modulate the gene expression of the mechanotransducers YAP and TAZ in human trabecular meshwork cells. Exp Eye Res 113:66-73

Tomarev SI, Wistow G, Raymond V, Dubois S, Malyukova I (2003) Gene expression profile of the human trabecular meshwork: NEIBank sequence tag analysis. Invest Ophthalmol Vis Sci 44:2588-2596

van Setten GB, Trost A, Schrodl F, Kaser-Eichberger A, Bogner B, van Setten M, Heindl LM, Grabner G, Reitsamer HA (2016) Immunohistochemical detection of CTGF in the human eye. Curr Eye Res 41:1571-1579

Wallace DM, Clark AF, Lipson KE, Andrews D, Crean JK, O'Brien CJ (2013) Anti-connective tissue growth factor antibody treatment reduces extracellular matrix production in trabecular meshwork and lamina cribrosa cells. Invest Ophthalmol Vis Sci 54:7836-7848

Weinreb RN, Aung T, Medeiros FA (2014) The pathophysiology and treatment of glaucoma: a review. JAMA 311:1901-1911

Yamamoto T, Sawada Y, Katayama I, Nishioka K (2005) Nodular scleroderma: increased expression of connective tissue growth factor. Dermatology 211:218-223

Yin Q, Liu H (2019) Connective tissue growth factor and renal fibrosis. Adv Exp Med Biol 1165:365-380

Publisher's Note Springer Nature remains neutral with regard to jurisdictional claims in published maps and institutional affiliations. 